\title{
Efficacy of Essential Oils in Pain: A Systematic Review and Meta-Analysis of Preclinical Evidence
}

\author{
Damiana Scuteri ${ }^{1,2}, K^{2}$ geno Hamamura ${ }^{3}$, Tsukasa Sakurada $^{4}$, Chizuko Watanabe ${ }^{5}$, \\ Shinobu Sakurada ${ }^{5}$, Luigi Antonio Morrone ${ }^{6}$, Laura Rombolà ${ }^{6 *}$, Paolo Tonin ${ }^{2}$, \\ Giacinto Bagetta $^{1 *}$ and Maria Tiziana Corasaniti ${ }^{7,8}$
}

\begin{abstract}
${ }^{1}$ Pharmacotechnology Documentation and Transfer Unit, Section of Preclinical and Translational Pharmacology, Department of Pharmacy, Health and Nutritional Sciences, University of Calabria, Rende, Italy, ${ }^{2}$ Regional Center for Serious Brain Injuries, S. Anna Institute, Crotone, Italy, ${ }^{3}$ Laboratory of Chemical Pharmacology, Faculty of Pharmaceutical Sciences, Daiichi University of Pharmacy, Fukuoka, Japan, ${ }^{4}$ Center for Supporting Pharmaceutical Education, Faculty of Pharmaceutical Sciences, Daiichi University of Pharmacy, Fukuoka, Japan, ${ }^{5}$ Department of Physiology and Anatomy, Faculty of Pharmaceutical Sciences, Tohoku Medical and Pharmaceutical University, Sendai, Japan, ${ }^{6}$ Section of Preclinical and Translational Pharmacology, Department of Pharmacy, Health and Nutritional Sciences, University of Calabria, Rende, Italy, ${ }^{7}$ Department of Health Sciences, University "Magna Graecia" of Catanzaro, Catanzaro, Italy, ${ }^{8}$ School of Hospital Pharmacy, University "Magna Graecia" of Catanzaro, Catanzaro, Italy
\end{abstract}

OPEN ACCESS

Edited by:

Francesca Guida, University of Campania Luigi Vanvitelli,

Reviewed by: Franca Marino, University of Insubria, Italy Agnieszka Barbara Najda, University of Life Sciences of Lublin,

Poland

*Correspondence: Giacinto Bagetta giacinto.bagetta@unical.it Laura Rombolà

laura.rombola@unical.it

Specialty section: This article was submitted to Inflammation Pharmacology,

a section of the journal

Frontiers in Pharmacology

Received: 10 December 2020 Accepted: 18 January 2021 Published: 01 March 2021

Citation:

Scuteri D, Hamamura K, Sakurada T, Watanabe C, Sakurada S, Morrone LA, Rombolà L, Tonin P, Bagetta $G$ and

Corasaniti MT (2021) Efficacy of Essential Oils in Pain: A Systematic Review and Meta-Analysis of Preclinical Evidence.

Front. Pharmacol. 12:640128. doi: 10.3389/fphar.2021.640128
Background: The demand for essential oils (EOs) has been steadily growing over the years. This is mirrored by a substantial increase in research concerned with EOs also in the field of inflammatory and neuropathic pain. The purpose of this present systematic review and meta-analysis is to investigate the preclinical evidence in favor of the working hypothesis of the analgesic properties of EOs, elucidating whether there is a consistent rational basis for translation into clinical settings.

Methods: A literature search has been conducted on databases relevant for medical scientific literature, i.e., PubMed/MEDLINE, Scopus, and Web of Science from database inception until November 2, 2020, following the PRISMA (Preferred Reporting Items for Systematic reviews and Meta-Analyses) criteria for systematic reviews and meta-analyses.

Results: The search was conducted in order to answer the following PICOS (participants/ population, interventions, comparisons, outcomes, and study design) question: are EOs efficacious in reducing acute nociceptive pain and/or neuropathic pain in mice experimental models? The search retrieved 2,491 records, leaving 954 studies to screen after the removal of duplicates. The title and abstract of all 954 studies were screened, which left 127 records to evaluate in full text. Of these, 30 articles were eligible for inclusion.

Conclusion: Most studies (27) assessed the analgesic properties of EOs on acute nociceptive pain models, e.g. the acetic acid writhings test, the formalin test, and the hot plate test. Unfortunately, efficacy in neuropathic pain models, which are a more suitable model for human conditions of chronic pain, had fewer results (only three studies). Moreover, some methodologies raised concerns in terms of the risk of bias. Therefore, EOs with proven efficacy in both types of pain were corroborated by methodologically consistent studies, like the EO of bergamot, which should be studied in clinical trials to enhance the translational impact of preclinical modeling on clinical pain research.

Keywords: essential oils, pain models, inflammatory pain, neuropathic pain, chronic pain, systematic review, metaanalysis 


\section{INTRODUCTION}

\subsection{Rationale}

Essential oils (EOs) containing components in exact proportion contributing synergically to the whole plant effect, have been used in traditional medicine for centuries since The Divine Farmer's Materia Medica, the first text of Chinese Traditional Medicine, representing a form of combinatorial medicine (Li and Weng, 2017). The search for natural and green products is constantly increasing the use of essential oils and the demand for these products from developing countries. There has been a remarkable increase in the import of EOs by the European market from 2011-2018 (Eurostat) and it is estimated that the demand for essential oils in the global market will grow by $7.5 \%$ from 2020 to 2027 (GVR, 2020). These data are mirrored by the steady increase of research on EOs that pave the way for the development of these products.

Identifying the year 1880 as this field emerged (Wood and Reichut, 1880), we found a remarkable increase in publications concerned with EOs up to 2020 (Figures 1A,B) (see also (Scuteri et al., 2017a)). EOs have shown several beneficial properties, many of which concern the treatment of neurologic diseases, mood disturbances, and pain. Modulation of the $\gamma$-aminobutyric acid (GABA) neurotransmission and blockade of neuronal voltage-gated sodium channels $(\mathrm{Na}+$ channels $)$ as well as activity on serotonergic neurotransmission are proposed as mechanisms involved in the action of EOs endowed with anxiolytic and anti-nociceptive properties like bergamot essential oil (BEO) (Rombolà et al., 2017; Scuteri et al., 2018a; Scuteri et al., 2019a; Scuteri et al., 2019b; Rombolà et al., 2019; Rombola et al., 2020), lavender essential oil (LEO) (Lopez et al., 2017), and melissa (lemon balm) (Abuhamdah et al., 2008; Awad et al., 2009). The cholinergic system is targeted by extracts of plants as sage (Perry et al., 2000; Savelev et al., 2003; Savelev et al., 2004), ginkgo (Stein et al., 2015; Zhang et al., 2018), and lemon balm (Dastmalchi et al., 2009; Guginski et al., 2009), showing therapeutic potential for diseases like dementia. The gathered evidence shows the potential benefits of EOs in the treatment of pain in fragile patients for whom several drugs can be more harmful, e.g. in aging or chronic neurologic diseases such as dementia (Achterberg et al., 2020). Pain is associated with mood disturbances (Evans, 1987; Husebo et al., 2011) influenced by aging (Hamm and Knisely, 1985; Scuteri et al., 2020a) and neuropathology (Scherder et al., 2003) and its treatment represents a field of strong inappropriateness in patients suffering from Alzheimer's disease. (Scuteri et al., 2017b; Scuteri et al., 2018b; Achterberg et al., 2020; Scuteri et al., 2020f). Therefore, aromatherapy represents a fundamental tool for the safer handling of pain.

Despite a large amount of continuously growing research on EOs, a real translation of aromatherapy into clinical settings and the treatment of pain has not occurred. Research efforts have aimed to discover the mechanisms at the root of the analgesic activity of EOs, often focusing on the single components commonly present in different plant oils e.g., linalool, limonene, pinene, eugenol, and cinnamal. For instance, linalool, limonene, and pinene contribute to the anxiolytic and antidepressant properties of some EOs (see (LizarragaValderrama, 2020)). In particular, some natural components of plants have been suggested as possible candidates for an analgesic action in neuropathic pain (Quintans et al., 2014). However, the strongest effect of EOs is due to the whole phytocomplex made up of various plant components that need to be present in a precise ratio to exert the so called entourage effect (Ribeiro, 2018). Definite combination of the constituents of EOs is necessary, but further studies are needed to highlight the exact active composition for each EO. The EOs of the species Citrus contain volatile components (85-99\%), most abundantly terpenoids, and a non-volatile fraction including coumarins i.e. bergapten inducing phototoxicity (Zaynoun et al., 1977). Thus, the EO of bergamot has been deprived of bergapten (Bagetta et al., 2010), but is still endowed
A

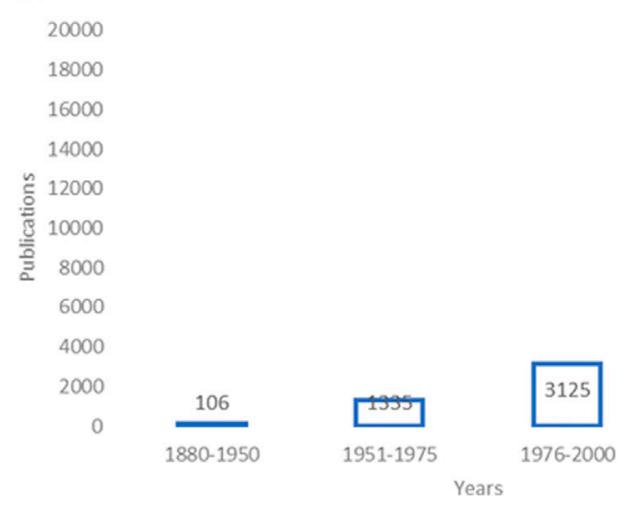

B

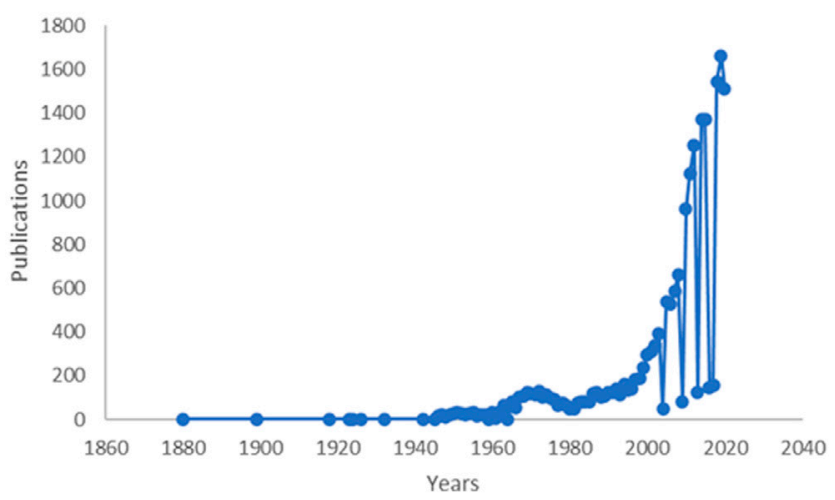

FIGURE 1 |Research in the field of essential oils (EOs) over the years.(A,B) Increase of research in the field of essential oils (EOs). (A) A PubMed advanced search using the key word "essential oils" combined with the dates of publication from 1880 to present through the Boolean operator AND has retrieved an increase from 106 to 17,212 (date of last search November 19, 2020) of results. The first interval "1880-1950" is wider because no great amount of research in this field has been detected up until the 1950s. (B) Data are presented per year of publication based on search query "essential oils" (date of last search November 25, 2020). Modified from (Scuteri et al., 2017a). 
with its characteristics. The EO of bergamot can modulate the synaptic level of glutamate and this occurs when it is used as a bergapten-free fraction (Morrone et al., 2007). Hence, a mixture of monoterpene hydrocarbons within the volatile fraction may be responsible for bergamot analgesic activity since glutamate is significantly involved in the pain descending pathway due to metabotropic glutamate receptors mGluR7 and mGluR8 (Boccella et al., 2020). The novel phytocannabinoid cannabidihexol, with the terpenophenolic core of cannabidiol and $\Delta 9$-tetrahydrocannabinol, has proven to significantly reduce the late phase of the formalin test at low doses in C57BL/6J mice (Linciano et al., 2020). Cannabidiol oil has been demonstrated to reduce traumatic brain injury-induced allodynia (Belardo et al., 2019). Certain EOs have been proven to have enhanced efficacy if combined: e.g., peppermint and caraway oil are significantly effective on post-inflammatory visceral hyperalgesia only when used in combination (Adam et al., 2006). Likewise, the route of administration and the time of exposure can influence the effects of EOs (Scuteri et al., 2018a; Koyama and Heinbockel, 2020). Moreover, some EOs are efficacious in a preclinical setting (Sarmento-Neto et al., 2015), but often only in a definite model of pain, usually acute e.g. the acetic acid-induced writhings, that does not find a significant counterpart in clinic. Furthermore, EOs are often administered as gavage or for inhalation not always allowing an exact determination of the dose.

Clinical trials in aromatherapy are few, small and methodologically limited, hence it is not always possible to draw rigorous conclusions, particularly in dementia. As recently demonstrated in a Cochrane systematic review by Ball et al. (2020), the design, reporting and consistency of outcome measurement have been identified as the weakest points and need to be improved in the future. Thus, despite accumulating preclinical and clinical evidence for EOs (Scuteri et al., 2020d) and nutraceuticals (Scuteri et al., 2020e) in lots of forms and supplements, which have been studied in several neurodegenerative conditions, a sound rationale for their clinical use, especially in treating chronic pain (Lakhan et al., 2016), has not yet emerged.

\section{METHODS}

\subsection{Objectives}

The present systematic review and meta-analysis aimed to verify the working hypothesis that EOs have analgesic properties by investigating preclinical evidence in favor of the latter, to understand whether there is a consistent rational basis for clinical translation. For this purpose, the objective was to assess the efficacy of EOs in preclinical models of both nociceptive and neuropathic pain through the PRISMA (Preferred Reporting Items for Systematic reviews and MetaAnalyses) (Liberati et al., 2009; Moher et al., 2009) criteria for systematic reviews and meta-analyses. The systematic review and meta-analysis focuses on the following PICOS (participants/ population, interventions, comparisons, outcomes, and study design) question: are EOs efficacious in reducing acute nociceptive pain and/or neuropathic pain in mice experimental models? In particular, this work aimed at evaluating:

- analgesic effectiveness (outcome);

- of EOs with a known composition (interventions), and not single components or extracts, administered intraperitoneally (i.p.) or subcutaneously (s.c.) to allow determination of the exact dose and reproducibility;

- in male mice subjected to nociceptive or neuropathic pain models (participants/population);

- with respect to providing a vehicle or other treatments (comparators);

- in studies designed according to legislation to minimize the suffering of animals (study design).

To the best of our knowledge, this is the first meta-analysis of preclinical studies on the analgesic effects of EOs interventions in models of both nociceptive and neuropathic pain.

\subsection{Protocol}

The search strategy and extraction of data to answer to PICOS question followed the PRISMA (Liberati et al., 2009; Moher et al., 2009) criteria. Due to the nature of preclinical animal intervention systematic review and meta-analysis, the latter aims at investigating the consistency of the body of evidence for clinical translation without an outcome of clear human relevance. For this reason, it has not been registered in the International prospective register of systematic reviews PROSPERO. However, statistically analyzing basic research independent studies testing the same hypothesis with comparable parameters can: determine its consistency allowing to study that phenomenon in a larger sample surmounting the issues concerned with small sample sizes; correct confounders; improve reproducibility (Editorial, 2016). Thus, a systematic review and meta-analysis is fundamental to establish a real possible clinical translation of a preclinically studied effect since it can highlight whether it has been consistently proven with the most reliable human disease modelled approach. Two independent researchers ran the search in agreement with the previously established protocol and inclusion and exclusion criteria, including double-checking the retrieved results, and any conflicts found by them were resolved by a third author.

\subsection{Eligibility Criteria}

\subsubsection{Inclusion Criteria}

The analysis included studies assessing the antinociceptive effect of EOs, administered i. p. or s. c. to allow determination of the exact dose and reproducibility, with a known percentage of components on male mice subjected to nociceptive or neuropathic pain models. Compliance with animal welfare regulations was an inclusion criterion of the utmost importance. The studies included needed to be designed according to legislation to minimize animal suffering. Either acute nociceptive or neuropathic pain models are included. Independently of the model used, the outcome of the study had to be antinociception for eligibility. 


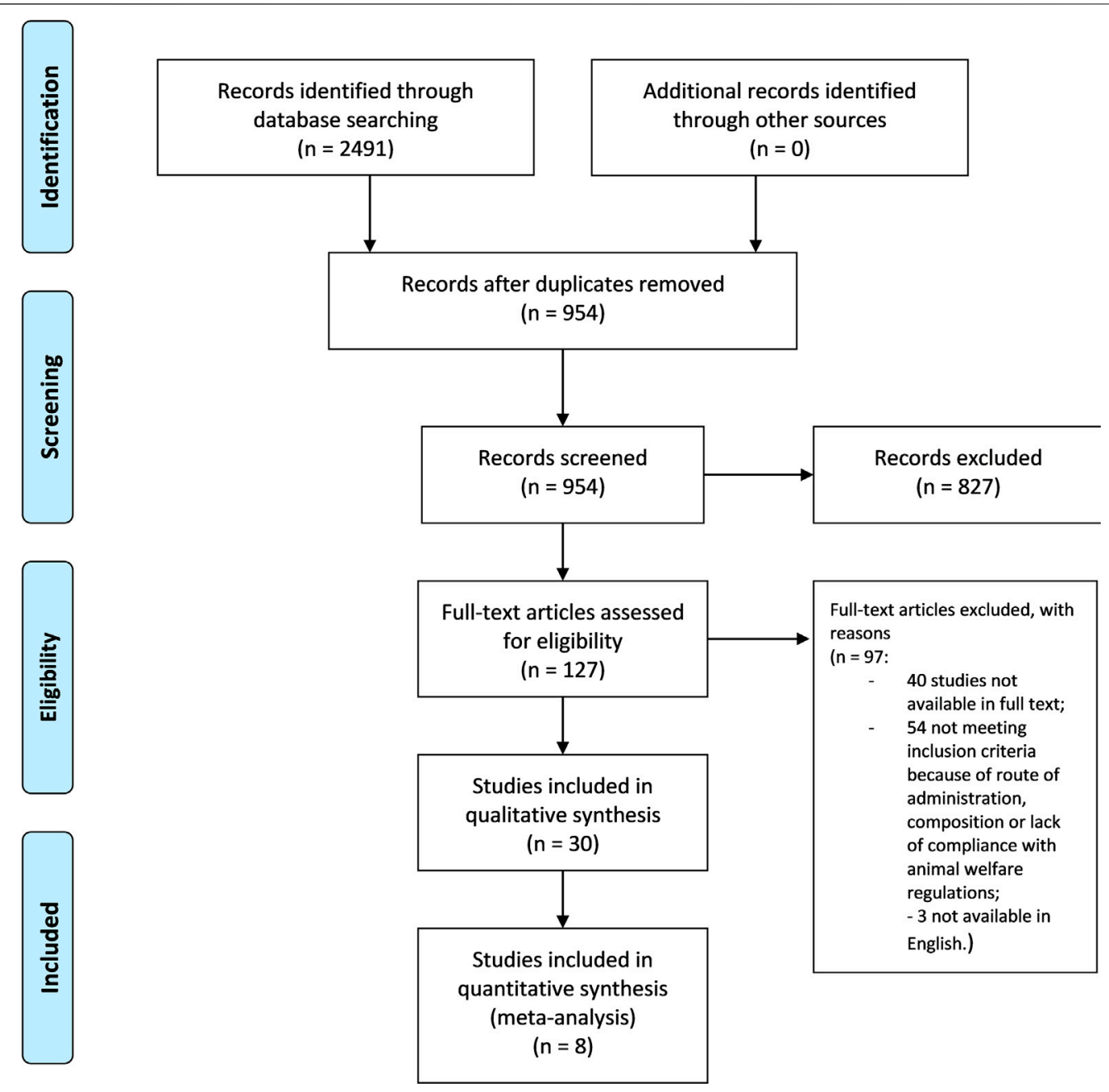

FIGURE 2 | Literature search and screening of retrieved records. PRISMA flow diagram (Moher et al., 2009) of the selection process of the studies eligible for qualitative and quantitative synthesis.

\subsubsection{Exclusion Criteria}

Studies on species different from mice or any strains and female gender were not eligible. The use of different species and genders would not allow comparison and the number of papers examining pain in non-rodent species is very small. Papers in which extracts or single plant components are used were excluded. Studies that did not consider ethics were excluded. Narrative or systematic reviews and meta-analysis, in vitro studies, abstracts and congress communications, proceedings, editorials, book chapters, and studies not published in English and not available in full text were not eligible.

\subsection{Information Sources}

A literature search was performed on PubMed/MEDLINE, Scopus, and Web of Science. Embase could not be searched as it was not freely/institutionally available. No restriction of publication date was applied and databases were searched for records matching the search strings used from their inception. The date of the last search was November 2, 2020. After the elimination of duplicate records, the first screening evaluated the title and abstract, and then the full text was assessed to define inclusion in qualitative and/or in quantitative synthesis.

\subsection{Search Strategy}

The following search terms and modifications were used as key words in combination: essential oils, pain, animal pain models, antinociceptive activity, allodynia, Von Frey ('s test), hyperalgesia, Hargreaves ('test), hot plate, capsaicin test, formalin test, tail flick test, acetone test, complete Freund's adjuvant, streptozocin, chemotherapy(-induced), oxaliplatin, cisplatin, paclitaxel, docetaxel, vincristine, vinblastine, eribulin, bortezomib, thalidomide, neuropathy, mice.

\subsection{Data Collection Process}

The eligibility of the studies was assessed independently by two authors to minimize the risk of excluding relevant records. The references list of the articles was examined to extend and refine the search. A complete consensus was reached and no relevant 
conflicts were raised. The selection process is illustrated in the PRISMA flow diagram (Figure 2).

\subsection{Synthesis, Risk of Bias, and Statistical Analysis}

A systematic and narrative synthesis of the results, according to the Cochrane Consumers and Communication Review Group guidelines (Ryan, 2019 http://cccrg.cochrane.org, March 13, 2019 (accessed DATE).) was carried out. The risk of bias (internal validity) and the quality of the studies was assessed by two independent researchers through tools specific to preclinical animal studies like the Systematic Review Center for Laboratory Animal Experimentation (SYRCLE's) risk of bias (RoB) tool (Hooijmans et al., 2014) and the Collaborative Approach to Meta-Analysis and Review of Animal Data from Experimental Studies (CAMARADES) checklist for study quality (Macleod et al., 2004). Any discrepancies were resolved through consensus or with the help of a third author.

Meta-analyses were conducted using Cochrane Review Manager 5.3 (RevMan5.3; Copenhagen: The Nordic Cochrane Center, The Cochrane Collaboration). A minimum of five articles per outcome measure was required according to the systematic review protocol for animal intervention studies by SYRCLE. When the tests included in articles were multiple and performed at different times and doses, only the most significant time point for pain development and progression in the specific model was considered for meta-analysis and only data related to the most efficacious dose were included. Studies expressing the analgesic outcome in a comparable way were included in the meta-analysis. Data available and comparable, but not expressed with the same measure of effect size as proportional reduction of outcome in treated animals relative to untreated controls were converted in mean and standard deviation to allow statistical comparison. Data not available and not extractable from graphs using digital ruler software, e.g., PlotDigitizer 2.6.9, were excluded from quantitative analysis. The Higgins $\mathrm{I}^{2}$ value was calculated to assess the heterogeneity of studies (Higgins and Thompson, 2002). Differences were presented as risk ratios (RR) including 95\% confidence intervals (CI), using a random effect model (DerSimonian and Kacker, 2007) to manage the eventual heterogeneity of the studies and to assess intra- and interstudy variation. Publication bias was assessed through Egger's linear regression test to measure funnel plot asymmetry, adjusted through the "trim and fill" method (Egger et al., 1997; Duval and Tweedie, 2000; Sterne and Egger, 2001).

\section{RESULTS}

\subsection{Selection Process and Data Collection}

The search retrieved 2,491 results from databases and there were no results from additional searches. The records were screened for duplicates, leaving 954 studies. Title and abstract screening led to an initial exclusion of narrative or systematic reviews and meta-analysis, in vitro studies, abstracts and congress communications, proceedings, editorials, book chapters. This left 127 records in full text. Among these, two had to be excluded because the text was in Chinese ( $\mathrm{Li}$ et al., 1991; Chen et al., 2011) and one was excluded because it was written in Spanish (Do Nascimento Silva et al., 2018). After full text screening, 30 studies were included in qualitative analysis: 40 studies were not available in full text and 54 were excluded because they did not meet inclusion criteria because of species used, route of administration, composition, or lack of compliance with animal welfare regulations. For instance, the study by Ali et al. (2012) in which the EO of Nepeta pogonosperma Jamzad et Assadi was proven to have significant efficacy at different doses in the tail-flick and formalin test in Wistar rats was therefore not eligible. Among the records included in qualitative analysis, eight were included in quantitative synthesis, reporting comparable outcomes and the exact number of animals used. The process of literature search and screening was illustrated in the PRISMA flow diagram (Moher et al., 2009) in Figure 2.

\subsection{Qualitative Synthesis}

The data obtained from the 46 studies included in the qualitative analysis were grouped according to Cochrane Consumers and Communication Review Group guidelines (Ryan, 2019 http:// cccrg.cochrane.org, March 13, 2019 (accessed DATE).). These groups were based on the experimental pain model used in 1) EOs showing analgesia in nociceptive models, and 2) EOs with analgesic properties in neuropathic pain. The majority (27/30) of the studies used an acute nociceptive model. Studies providing a range and not an exact number of animals per group were not considered eligible for quantitative analysis. Studies expressing the analgesic outcome in a not comparable manner to the majority were excluded from the meta-analysis. The main characteristics of the studies with reference to the PICOS question are reported in Tables 1, 2.

\subsubsection{Essential Oils Endowed With Efficacy in Acute Nociceptive Models}

Based on the obtained results, several EOs showed analgesic activity in acute nociceptive tests like the acetic acid writhings test, hot-plate test, and the formalin test, with the latter very useful since it includes features of both peripheral and central pain. In the study by Anaya-Eugenio et al. (2016) the EO of artemisia ludoviciana Nutt (Asteraceae) exerted dose-dependent antinociceptive activity in the hot-plate and the formalin test. It was less potent than the reference drug morphine and antagonism studies have revealed that it was inhibited by the non-selective opioid receptor antagonist naloxone. Inula britannica L (Asteraceae) has shown analgesia in the acetic acid writhings test, in the formalin test, in the tail-flick, and the glutamate test (Zarei et al., 2018). This effect is reversed by naloxone and potentiated by L-arginine, therefore all the studies performed with negative and positive controls highlighted the involvement of the opioid system and NO pathway (Zarei et al., 2018).

The EO of Myrcia pubiflora DC., Myrtaceae (Andrade et al., 2012) has demonstrated analgesic efficacy in the acetic acid 
writhings test and the formalin test, but not in the hot plate test. From the same family, the EO of Eugenia candolleana DC (Myrtaceae) reduced the number of writhings and licking behavior in the second phase of the formalin test in a dosedependent manner (only at the dose of $100 \mathrm{mg} / \mathrm{kg}$ in the first phase, but not the nociceptive reaction in the hot-plate test (Guimaraes et al., 2009)).

Clove bud oil (Eugenia caryophyllata, Myrtaceae) significantly reduced formalin-induced pain behavior but affected tail-flick response in a variable way (Halder et al., 2012). The study by Bae et al. (2020) considered basil for its i. p. administration and demonstrated analgesic properties linked to action on $\delta$ - and $\mu$-opioid pathways. Moreover, it provides orofacial antinociception at high doses (Venâncio et al., 2011). Aristolochia trilobata L. demonstrated strong analgesia in the formalin test and was comparable to morphine in the acetic acid test (Quintans et al., 2017).

The EO of Croton conduplicatus Kunth (Euphorbiaceae) has shown efficacy (de Oliveira Júnior et al., 2017; de Oliveira et al., 2018): in the acetic acid test; on the formalin-induced nociceptive behavior at all the doses and in both phases, with effect antagonized by naloxone; on nociception in term of latency time at the highest dose (50 (deOliveira et al., 2018) and 100 (de Oliveira Júnior et al., 2017) $\mathrm{mg} / \mathrm{kg}$ ) in the hot-plate test. In particular, the mechanism of action of this EO has been proposed to be influenced by ATP-sensitive $\mathrm{K}+$ channels, opioid and cholinergic systems (de Oliveira Júnior et al., 2017; de Oliveira et al., 2018).

Croton cordiifolius Baill (Euphorbiaceae) also had effective results in acetic acid, formalin, and glutamate but not the capsaicin test. This antinociceptive effect was independent on naloxone (Nogueira et al., 2015). Croton adamantinus Müll. Arg. showed a strongly effective comparison with morphine in reducing licking and was more efficacious than indomethacin in decreasing abdominal contortions (Ximenes et al., 2013). Of the study by Hajhashemi et al. (2009) only the experiments using the EO i. p. and on mice could be included in the analysis, showing the effectiveness of Heracleum persicum to be almost comparable to indomethacin in the reduction of the number of writhings.

In the study by Jahandar et al. (2018) only the experiments performed on mice were considered. Pycnocycla bashagardiana (Apiaceae) has not proven analgesic but anti-inflammatory properties. In another study by Ulku Karabay-Yavasoglu et al. (2006) only experiments with the formalin test in mice were considered. The EO of Satureja thymbra L (Lamiaceae) was demonstrated to have antinociceptive efficacy in both the early and late (also at a lower dose) phases of the formalin test (Ulku Karabay-Yavasoglu et al., 2006).

In the study by Katsuyama et al. (2015) the EO of bergamot (Citrus bergamia Risso) demonstrated significant dosedependent analgesia in both phases of the formalin test, only when administered in the ipsilateral hindpaw and antagonized by naloxone hydrochloride and methiodide (not able to cross the blood brain barrier), suggesting the involvement of peripheral opioid mechanisms. This was earlier observed in the capsaicin test in which it also enhanced morphine analgesia (Sakurada et al., 2011).
Neroli (Citrus aurantium L.) significantly increases reaction time (at $40 \mathrm{mg} / \mathrm{kg}$ ) in the hot-plate test and significantly decreased the number of writhings in the study by Khodabakhsh et al. (2015), with the latter effect potentiated by L-nitro arginine methyl ester (L-NAME). In the study by Khalid et al. (2011) the EO of Zingiber zerumbet (L.) Smith, dosedependent and comparable to acetylsalicylic acid, inhibited the nociceptive response to capsaicin, acetic acid, glutamate, and phorbol 12-myristate 13-acetate (PMA). Eucalyptus EO has significantly reduced licking time in the second phase of the formalin test in the study by Lee et al. (2019), and this effect was mediated by the opioid system. It also reduced the number of writhings in a dose-dependent manner but did not display activity on thermal hyperalgesia (Lee et al., 2019). In the study by Lima et al. (2012) the EO of Chrysopogon zizanioides L (Roberty, Poaceae) produced antinociception similar to morphine in the acetic acid test, and this effect was partially reversed by naloxone. Moreover, it reduced the licking time in the second phase of the formalin test, but it did not demonstrate any effects in the Hargreaves' test.

A common trait is the presence of antiinflammatory analgesia devoid of thermal anti-hyperalgesic effect. The EO of Zhumeria majdae Rech. F. and Wendelbo (Lamiaceae) has displayed doserelated antinociceptive properties in the acetic acid and in the hot-plate test (Miraghazadeh et al., 2015). Chamaecyparis obtuse has also shown analgesia in the writhings and in the formalin, but not in the hot-plate test (Park et al., 2015). Furthermore, in the study by Mishra et al. (2010) Senecio rufinervis D.C. (Asteraceae) produced significant and dose-dependent inhibition of writhes and thermal hyperalgesia. In the study by Sharif et al. (2020) Tanacetum balsamita (Compositae) presented an antihyperalgesic effect. The antinociceptive properties exerted by Xylopia laevigata (Annonaceae) in the acetic acid and in the formalin test have not proven dependency on opioid pathways (Queiroz et al., 2014). The antinociceptive effect of Bunium persicum (Boiss.) is reversed by naloxone and attenuated by chlorpheniramine and cimetidine (Zendehdel et al., 2015), thus confirming the complex neuromodulation and the involvement of histamine in nociception (Hayashi et al., 2020). The main features of the studies on EOs analgesia in nociceptive models are summarized in Table $\mathbf{1 .}$

\subsubsection{Essential Oils Endowed With Efficacy in Neuropathic Models}

Studies assessing the analgesic properties of EOs in neuropathic pain models are fundamental because these painful conditions are the most appropriate to model chronic neuropathic pain in humans. In the study by Komatsu et al. (2018) the EO of bergamot (Citrus bergamia Risso) was demonstrated to reduce partial sciatic nerve ligation (PSNL)-induced mechanical allodynia on the seventh post-operative day, in which it peaks (Kusunose et al., 2010). In the study by Kuwahata et al. (2013) the EO of bergamot increased mechanical thresholds dosedependently and significantly at a dose of $20 \mu \mathrm{g} / \mathrm{paw}$ (Kuwahata et al., 2013). Moreover, this anti-allodynic effect is stronger than that of comparable doses of 
TABLE 1 | Main characteristics of the studies included showing the efficacy of EOs in nociceptive models.

\begin{tabular}{|c|c|c|c|c|c|}
\hline Study & $\begin{array}{c}\text { EO [most representative } \\
\text { components] }\end{array}$ & $\begin{array}{c}\text { Route of } \\
\text { administration }\end{array}$ & Control & $\begin{array}{l}\text { Mice } \\
\text { strain }\end{array}$ & Pain model \\
\hline $\begin{array}{l}\text { Anaya-Eugenio et al. } \\
\text { (2016) }\end{array}$ & $\begin{array}{l}\text { Artemisia ludoviciana [7)- } \\
\text { camphor ( } 21 \%), \gamma \text {-terpineol } \\
\text { (18\%), borneol } \\
\text { (18\%),terpine-4-ol } \\
(3.5 \%), 1,8 \text {-cineole } \\
(3.4 \%), \text { lavanderlactone } \\
(3.4 \%), \text { isoborneol } \\
(2.4 \%), \text { camphen-6-ol } \\
(2.3 \%), \text { trans-sabinylacet-ate } \\
(2.2 \%), \text { andbornylacetate } \\
(2.2 \%]\end{array}$ & i.p & Saline & $\begin{array}{l}\text { ICR } \\
\text { mice }\end{array}$ & $\begin{array}{l}\text { 1) Hot-plate } \\
\text { test and 2) } \\
\text { formalin test }\end{array}$ \\
\hline
\end{tabular}

\section{Andrade et al. (2012) Myrcia pubiflora DC., myrtaceae [caryophyllene oxide $(22.2 \%)$, mustakone (11.3\%), 1,8-cineole (5.4\%), and tricyclene (5.3\%)] \\ Bae et al. (2020) \\ Ocimum basilicum L. (basil, lamiaceae) [linalool (56.6\%), eugenol (18.1\%), 1,8-cineole (6.93\%), $\gamma$-cadinene (6.43\%), and $\beta$-pinene (1.84\%)]}

Aristolochia trilobata L. [6- i.p methyl-5-hepten-2-ylacetate (SA) $(21.49 \pm 0.43 \%)$, germacrene D $(15.07 \pm$ $0.23 \%)$, bicyclogermacrene $(8.84 \pm 0.45 \%)$, linalool $(6.85 \pm 0.42 \%)$, (E)caryophyllene $(5.58 \pm$ $0.12 \%),(E)-\beta$-ocimene $(5.56 \pm 0.067 \%)$ and p-cymene $(4.68 \pm 0.10 \%)]$ Croton conduplicatus kunth [E)-caryophyllene (13.72\%), and caryophyllene oxide (13.15\%) and monoterpene camphor (8.25\%)] de Oliveira et al. (2018)
Croton conduplicatus kunth [monoterpenes 1,8-cineole $(21.42 \%)$ and $p$-cymene (12.41\%) and sesquiterpenes spathulenol (15.47\%) and caryophyllene oxide (12.15\%)]
Control $(0.9 \%$ saline); vehicle (almond oil)

Vehicle (saline $+0.2 \%$ tween

Vehicle $(0.9 \%$ saline $+10 \mu \mathrm{L}$ of tween 80 , $10 \mathrm{ml} / \mathrm{kg}$ )
Swiss mice

Swiss mice

1) Acetic acid-induced writhing test, 2) formalin test and 3) hot plate test

\section{Analgesic outcome \\ and \\ sample size}

1) Dose-dependent

1) Dose-dependent antinociceptive action $(n=8) ; 2)$ effectiveness in the first phase at the highest dose and in dose-dependent manner in the second phase $(n=8)$
1) Acetic acid-induced writhing test, 2) formalin test and 3) hot plate test

1) Acetic acid-induced writhing test 2) formalin test and 3) hargreaves' test $(n=9)$

1) Acetic acid test and 2) formalin test
All the doses $(25,50$, and $100 \mathrm{mg} / \mathrm{kg}$ ) were active in acetic acid $(n=8)$ and formalin test $(n=8)$ and no dose in hot plate test ( $n=8)$ EO $(45 \mathrm{mg} / \mathrm{kg})$ is effective in 1) acetic acid test $(n=8-10)$ and in 2) the second phase $(n=7-12)$, but only at a much higher dose $(180 \mathrm{mg} / \mathrm{kg})$ in 3) the hargreaves' test $(n=9)$

1) EO (25, 50 and 100 $\mathrm{mg} / \mathrm{kg}$ ) has exerted analgesia comparable to morphine and sulcatyl acetate $(n=8)$; 2) $\mathrm{EO}(25,50$ and 100 $\mathrm{mg} / \mathrm{kg}$ ) has resulted active in the second phase and only at the highest dose in the first phase $(n=8)$ EO has resulted active at all doses in acetic acid $(n=6)$ and formalin test $(n=6)$ and at dose of $50 \mathrm{mg} / \mathrm{kg}$ in the hotplate test $(n=6)$

1) Acetic acid-induced writhing test, 2) formalin test and 3) hot plate test

EO (25, 50 and $100 \mathrm{mg} / \mathrm{kg}$ ) has resulted active in acetic acid $(n=6)$ and formalin test $(n=6)$ and no dose in hot plate test $(n=6)$
Use of increasing

logarithmic dose $(1,10$, $17.7,31.6$, and $100 \mathrm{mg} / \mathrm{kg}$ ) according to allometric scaling. Use of a References drug: morphine sulfate. Antagonism studies with naloxone, atropine sulfate, L-nitro arginine methyl ester (L-NAME), or glibenclamide. No sample power calculation, randomization or blinding, or conflict of interest statement

Random housing. Experiments performed between 9am and 4pm. Use of References drug morphine. No conflict of interest statement

Positive and negative control drugs have been used: morphine, indomethacin, naloxone, 5'-guanidinonaltrindole, naltrindole, L-NAME; L-arginine, and glibenclamide-hippuric acid. Mice have been randomly divided into groups. No conflict of interest statement

Mice have been randomly assigned to groups.

Experiments have been carried out from 08:00 a.m. to $04: 00$ p.m. (during light period) and in a blind manner. Morphine, acetylsalicylic acid and sulcatyl acetatehave been used as positive controls. No conflict of interest statement All the studies have been carried out by the same observers. Morphine and indomethacin as positive control. Antagonism studies (glibenclamide, naloxone and atropine). Random housing. Declaration of no conflict of interest

All the studies have been carried out by the same observers. Morphine and indomethacin as positive control. Antagonism studies (naloxone, atropine and flumazenil). Random housing. Declaration of no conflict of interest

(Continued on following page) 
TABLE 1 | (Continued) Main characteristics of the studies included showing the efficacy of EOs in nociceptive models.

\begin{tabular}{|c|c|c|c|c|c|c|c|}
\hline Study & $\begin{array}{c}\text { EO [most representative } \\
\text { components] }\end{array}$ & $\begin{array}{c}\text { Route of } \\
\text { administration }\end{array}$ & Control & $\begin{array}{l}\text { Mice } \\
\text { strain }\end{array}$ & Pain model & $\begin{array}{c}\text { Analgesic outcome } \\
\text { and } \\
\text { sample size }\end{array}$ & Design \\
\hline $\begin{array}{l}\text { Guimaraes et al. } \\
\text { (2009) }\end{array}$ & 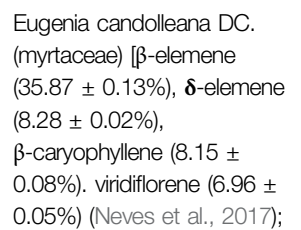 & i.p & $\begin{array}{l}\text { Vehicle (saline }+1 \\
\text { drop of Tween- } \\
800.2 \% \text { ) }\end{array}$ & $\begin{array}{l}\text { Swiss } \\
\text { mice }\end{array}$ & $\begin{array}{l}\text { 1) acetic acid- } \\
\text { induced } \\
\text { writhing test, } \\
\text { 2) formalin } \\
\text { test and 3) } \\
\text { hot plate test }\end{array}$ & $\begin{array}{l}\text { EO }(25,50 \text {, and } 100 \\
\text { mg/kg) dose- } \\
\text { dependently inhibits } \\
\text { acetic acid }(n=10) \\
\text { and formalin-induced } \\
(n=10), \text { but not hot- } \\
\text { plate }(n=10) \text { behaviors }\end{array}$ & $\begin{array}{l}\text { Experiments carried out } \\
\text { between 09:00 h and 16: } \\
00 \mathrm{~h} \text {. References drug was } \\
\text { acetylsalicylic acid. } \\
\text { Random housing. No } \\
\text { conflict of interest } \\
\text { statement }\end{array}$ \\
\hline
\end{tabular}

Halder at al. (2012) Eugenia caryophyllata (clove

oil; myrtaceae) [eugeno

(87.34\%), eugenyl acetate

(5.18\%), and beta-

caryophyllene (2.01\%)]

$\begin{array}{lll}\begin{array}{l}\text { Vehicle (1\% } \\ \text { solution of tween }\end{array} & \begin{array}{l}\text { Swiss } \\ \text { mice }\end{array} & \begin{array}{l}\text { Acetic acid- } \\ \text { induced } \\ \text { writhing test }\end{array} \\ & & \\ 0.9 \% \text { saline } & \begin{array}{l}\text { Swiss } \\ \text { mice }\end{array} & \begin{array}{l}\text { 1) Formalin } \\ \text { test and 2) } \\ \text { tail-flick test }\end{array}\end{array}$

Khalid et al. (2011)

Zingiber zerumbet (L.) smith [zerumbone (36.12\%), humulene (10.03\%), humulene oxide I (4.08\%), humulene oxide II (2.14\%), caryophyllene oxide II (1.66\%) and caryophyllene oxide I (1.43\%), camphene (14.29\%), borneol (4.78\%), camphor (4.18\%), eucalyptol (3.85\%), a-pinene (3.71\%), $\gamma$-terpinene $(2.00 \%)$, $\beta$-phellandrene (1.63\%), 1 terpen4-ol (1.44\%), $\beta$-myrcene (1.22\%) and linalool (1.06\%), as previously described Sulaiman et al. (2010)]

Jahandar et al. (2018)

\section{i.p}

Vehicle

ICR

mice

Capsaicin,

acetic acid,

glutamate

and phorbol

12-myristate

13-acetate

(PMA)-

induced

nociception

i.p
Vehicle
Pycnocycla bashagardiana (apiaceae) [myristicin (76.1\%), E. $\beta$. Ocimene (4.1\%), Z. $\beta$. Ocimene (3.8\%) and $\beta$-eudesmol (2.9\%)]
EO (50-100 mg/kg)

has reduced

writhings of 66 and

$73 \%$ respectively $(n=$

$6)$, in comparison with the $80 \%$ reduction of indomethacin

1) $E O(0.1 \mathrm{ml} / \mathrm{kg})$ has reduced licking/biting time in the first and $(0.025,0.05$, and $0.1 \mathrm{ml} / \mathrm{kg}$ ) in the second phase $(n=6)$; 2) effect of clove oil $(0.1 \mathrm{ml} / \mathrm{kg})(n=6)$ at $30 \mathrm{~min}$ of reduced tailflick latency resulted reverted by naloxone. Though not significantly, the dose $0.025 \mathrm{ml} / \mathrm{kg}$ of clove oil, at 30 and $60 \mathrm{~min}$ have increased the mean tail-flick latency EO $(50,100,200$, $300 \mathrm{mg} / \mathrm{kg}$ ) has exerted significant dose-dependent inhibition of: abdominal writhings ( $n=10$ ); capsaicininduced neurogenic nociception $(n=10)$ similar to that of acetylsalicylic acid and of capsazepine; glutamate-induced nociception $(n=10)$ and of PMA-induced nociception ( $n=10)$, comparable to acetylsalicylic acid 1) $E O(100,200$, and $400 \mathrm{mg} / \mathrm{kg}$ ) has not shown antinociceptive activity in the formalin test ( $n=6-8)$; 2) EO (50, 100, 200, and $400 \mathrm{mg} / \mathrm{kg}$ ) has not shown antinociceptive activity in the hot-plate test
Indomethacin has been used as positive control. No conflict of interest statement

Experiments performed at daytime between 09:30 and 15:30. Morphine and acetylsalicylic acid have been used as References drugs. Naloxone has been used in the tail-flick test. No conflict of interest statement

Blinded, randomized and controlled design. Acetylsalicylic acid and capsazepine have been used as References drug. Antagonism studies with L-arginine, $\mathrm{N}^{\dot{\omega}}$-nitroL-arginine, methylene blue and glibenclamide. No conflict of interest statement

Morphine had been used as References drug. Declaration of no conflict of interest 
TABLE 1 | (Continued) Main characteristics of the studies included showing the efficacy of EOs in nociceptive models.

\begin{tabular}{|c|c|c|c|c|c|c|c|}
\hline Study & $\begin{array}{c}\text { EO [most representative } \\
\text { components] }\end{array}$ & $\begin{array}{c}\text { Route of } \\
\text { administration }\end{array}$ & Control & $\begin{array}{l}\text { Mice } \\
\text { strain }\end{array}$ & Pain model & $\begin{array}{c}\text { Analgesic outcome } \\
\text { and } \\
\text { sample size }\end{array}$ & Design \\
\hline $\begin{array}{l}\text { Katsuyama et al. } \\
\text { (2015) }\end{array}$ & $\begin{array}{l}\text { Bergamot (citrus bergamia } \\
\text { risso) [0.38\% D-limonene, } \\
70.26 \% \text { linalyl acetate, } \\
18.95 \% \text { linalool, } 0.62 \% \\
\gamma \text {-terpinene, and } 0.03 \% \\
\beta \text {-pinene] }\end{array}$ & S.C & $\begin{array}{l}\text { Jojoba wax and } \\
\text { none }\end{array}$ & $\begin{array}{l}\text { ddY } \\
\text { mice }\end{array}$ & Formalin test & $\begin{array}{l}\text { Significant dose- } \\
\text { dependent inhibition } \\
\text { of both phases by EO } \\
(2.5,5,10 \boldsymbol{\mu g})(n=10)\end{array}$ & $\begin{array}{l}\text { All behavioral experiments } \\
\text { have been carried out } \\
\text { during the light period } \\
\text { between 10:00 and 16:00. } \\
\text { The animals have been } \\
\text { tested in randomized order. } \\
\text { Antagonism studies with } \\
\text { naloxone hydrochloride and } \\
\text { naloxone methiodide. No } \\
\text { conflict of interest } \\
\text { statement }\end{array}$ \\
\hline $\begin{array}{l}\text { Khodabakhsh et al. } \\
\text { (2015) }\end{array}$ & $\begin{array}{l}\text { Neroli (citrus aurantium L.) } \\
\text { [linalool }(28.5 \%), \text { linalyl } \\
\text { acetate }(19.6 \%), \text { nerolidol } \\
\text { (9.1\%), and E,E- } \\
\text { farnesol }(9.1 \%)]\end{array}$ & i.p & $\begin{array}{l}\text { Vehicle } \\
\text { (sweet almond oil) }\end{array}$ & $\begin{array}{l}\text { Wistar } \\
\text { mice }\end{array}$ & $\begin{array}{l}\text { 1)acetic acid } \\
\text { and 2) hot- } \\
\text { plate test }\end{array}$ & $\begin{array}{l}\text { 1) Neroli (10 and } \\
20 \mathrm{mg} / \mathrm{kg} \text { ) has } \\
\text { significantly } \\
\text { decreased the } \\
\text { number of writhings } \\
(n=8) \text { and } 2 \text { ) has } \\
\text { significantly } \\
\text { increased latency } \\
\text { time at dose of } \\
40 \mathrm{mg} / \mathrm{kg}(n=8)\end{array}$ & $\begin{array}{l}\text { Mice have been used only } \\
\text { once and experiments have } \\
\text { been conducted between } \\
10.00 \text { a.m. and } 13 \text { p.m. } \\
\text { with normal room light. } \\
\text { Diclofenac has been used } \\
\text { as References drug and } \\
\text { L-NAME as enhancer. No } \\
\text { References to } \\
\text { randomization of mice but } \\
\text { only for the experimental } \\
\text { part concerned with rats. } \\
\text { No conflict of interest } \\
\text { statement. }\end{array}$ \\
\hline Lee et al. (2019) & $\begin{array}{l}\text { Eucalyptus [(aromarant co. } \\
\text { Ltd., rottingen, Germany); } \\
\text { 1,8-cineole (61.46\%), } \\
\text { limonene (13.68\%), } \\
\rho \text {-cymene (8.55\%), } \\
\gamma \text {-terpinene (5.87\%), } \\
\text { a-pinene (4.95\%), and } \\
\text { a-phellandrene (1.09\%) Jun } \\
\text { et al. (2013)] }\end{array}$ & i.p & $\begin{array}{l}\text { Control } 0.9 \% \\
\text { saline and vehicle } \\
\text { (almond oil) }\end{array}$ & $\begin{array}{l}\text { C57BL/ } \\
6 \text { mice }\end{array}$ & $\begin{array}{l}\text { 1) Formalin } \\
\text { test, 2) acetic } \\
\text { acid test and } \\
\text { 3) } \\
\text { hargreaves' } \\
\text { test }\end{array}$ & $\begin{array}{l}\text { 1) EO (11.5, } 22.5 \text {, } \\
45 \mathrm{mg} / \mathrm{kg} \text { ) has } \\
\text { significantly reduced } \\
\text { licking time in the } \\
\text { second phase ( } n= \\
7-12) ; 2) \text { dose- } \\
\text { dependent reduction } \\
\text { of the number of } \\
\text { writhes ( } n=8-10) ; 3 \text { ) } \\
\text { no significant effect } \\
(n=10)\end{array}$ & $\begin{array}{l}\text { Antagonism studies with } \\
\text { the k-opioid antagonist } 5^{\prime} \text { - } \\
\text { guanidinonaltrindole, the } \\
\boldsymbol{\delta} \text {-opioid antagonist } \\
\text { naltrindole and the } \boldsymbol{\mu} \text {-opioid } \\
\text { antagonist naloxone (also + } \\
\text { morphine). Indomethacin } \\
\text { has been used as } \\
\text { References drug for acetic } \\
\text { acid test. Declaration of no } \\
\text { conflict of interest }\end{array}$ \\
\hline Lima et al. (2012) & $\begin{array}{l}\text { Chrysopogon zizanioides L. } \\
\text { (roberty, poaceae) [khusimol } \\
(19.57 \%), \text { E-isovalencenol } \\
(13.24 \%), a \text {-vetivone } \\
(5.25 \%), \text { vetiselinenol } \\
\text { (5.08\%), a-cadinol (5.01\%), } \\
\text { a-vetivone (4.87\%) and } \\
\text { hydroxy-valencene (4.64\%)] }\end{array}$ & i.p & $\begin{array}{l}\text { Vehicle (distilled } \\
\text { water with one } \\
\text { drop of tween } \\
800.2 \% \text { ) }\end{array}$ & $\begin{array}{l}\text { Swiss } \\
\text { mice }\end{array}$ & $\begin{array}{l}\text { 1) Formalin } \\
\text { test, 2) acetic } \\
\text { acid test and } \\
\text { 3) hot-plate } \\
\text { test }\end{array}$ & $\begin{array}{l}\text { 1) EO ( } 50 \text {, and } \\
100 \mathrm{mg} / \mathrm{kg}) \text { has been } \\
\text { effective in the } \\
\text { second phase ( } n= \\
10) ; 2) \mathrm{EO}(50, \text { and } \\
100 \mathrm{mg} / \mathrm{kg}) \text { has } \\
\text { produced } \\
\text { antinociception } \\
\text { similar to morphine } \\
(n=10) ; 3) \mathrm{EO}(25 \text {, } \\
50, \text { and } 100 \mathrm{mg} / \mathrm{kg}) \\
\text { has not shown } \\
\text { efficacy }(n=10)\end{array}$ & $\begin{array}{l}\text { Morphine and } \\
\text { acetylsalicylic acid have } \\
\text { been used as References } \\
\text { drugs and naloxone for } \\
\text { antagonism study. Random } \\
\text { housing. No conflict of } \\
\text { interest statement }\end{array}$ \\
\hline Ximenes et al. (2013) & $\begin{array}{l}\text { Croton adamantinus müll. } \\
\text { Arg. [Methyl-eugenol } \\
(14.81 \%), 1,8 \text {-cineole } \\
(13.74 \%), \\
\text { bicyclogermacrene }(8.06 \%) \\
\text { and } \\
\beta \text {-caryophyllene (5.80\%)] }\end{array}$ & i.p & $\begin{array}{l}\text { Vehicle } \\
\text { (cremophor } \\
0.5 \% \\
0.1 \mathrm{ml} / 10 \mathrm{~g} \text { ) }\end{array}$ & $\begin{array}{l}\text { Swiss } \\
\text { mice }\end{array}$ & $\begin{array}{l}\text { 1) Formalin } \\
\text { test and 2) } \\
\text { acetic acid } \\
\text { test }\end{array}$ & $\begin{array}{l}\text { 1) EO ( } 50 \text { and } \\
150 \mathrm{mg} / \mathrm{kg}) \text { is } \\
\text { effective in both } \\
\text { phases, and in a } \\
\text { comparable way to } \\
\text { morphine in the } \\
\text { second phase; 2) EO } \\
\text { ( } 50 \text { and } 150 \mathrm{mg} / \mathrm{kg}) \text { is } \\
\text { more effective than } \\
\text { indomethacin. } \\
\text { Unreported number } \\
\text { of animals }\end{array}$ & $\begin{array}{l}\text { For the acetic acid test, the } \\
\text { observation has been } \\
\text { conducted by a blind } \\
\text { observer. Morphine and } \\
\text { indomethacin have been } \\
\text { used as References drugs. } \\
\text { No conflict of interest } \\
\text { statement }\end{array}$ \\
\hline
\end{tabular}

(Continued on following page) 
TABLE 1 | (Continued) Main characteristics of the studies included showing the efficacy of EOs in nociceptive models.

\begin{tabular}{|c|c|c|c|c|c|c|c|}
\hline Study & $\begin{array}{c}\text { EO [most representative } \\
\text { components] }\end{array}$ & $\begin{array}{c}\text { Route of } \\
\text { administration }\end{array}$ & Control & $\begin{array}{l}\text { Mice } \\
\text { strain }\end{array}$ & Pain model & $\begin{array}{c}\text { Analgesic outcome } \\
\text { and } \\
\text { sample size }\end{array}$ & Design \\
\hline $\begin{array}{l}\text { Miraghazadeh et al. } \\
\text { (2015) }\end{array}$ & $\begin{array}{l}\text { Zhumeria majdae rech. F. } \\
\text { and wendelbo (lamiaceae) } \\
\text { [linalool }(63.4 \%) \text { and } \\
\text { camphor }(27.5 \%)]\end{array}$ & i.p & $\begin{array}{l}\text { Vehicle } \\
\text { (sweet almond oil) }\end{array}$ & $\begin{array}{l}\text { NMRI } \\
\text { mice }\end{array}$ & $\begin{array}{l}\text { 1) Acetic acid } \\
\text { test; 2) hot- } \\
\text { plate test }\end{array}$ & $\begin{array}{l}\text { 1) } \mathrm{EO}(5,10,20 \text {, } \\
40 \mathrm{mg} / \mathrm{kg}) \text { has } \\
\text { produced dose- } \\
\text { dependent analgesia } \\
(n=5) ; 2) \mathrm{EO}(5,20, \\
40 \mathrm{mg} / \mathrm{kg}) \text { has } \\
\text { significantly } \\
\text { prolonged latency } \\
\text { time in dose-related } \\
\text { manner }(n=5)\end{array}$ & $\begin{array}{l}\text { Experiments have been } \\
\text { conducted between } 10.00 \\
\text { a.m. and } 13.00 \text { p.m. and } \\
\text { mice used only once. } \\
\text { Diclofenac has been used } \\
\text { as References drug. No } \\
\text { conflict of interest } \\
\text { statement }\end{array}$ \\
\hline Mishra et al. (2010) & $\begin{array}{l}\text { Senecio rufinervis D.C. } \\
\text { (Asteraceae) [germacrene D } \\
\text { (40.19\%), } \beta \text {-pinene } \\
(12.23 \%), \beta \text {-caryophyllene } \\
(6.21 \%) \text { and } \\
\beta \text {-longipinene }(4.15 \%)]\end{array}$ & i.p & $\begin{array}{l}\text { Vehicle }(2 \% \mathrm{v} / \mathrm{v} \\
\text { tween } 80)\end{array}$ & $\begin{array}{l}\text { Wistar } \\
\text { albino } \\
\text { mice }\end{array}$ & $\begin{array}{l}\text { 1) Acetic acid } \\
\text { test; 2) hot- } \\
\text { plate test }\end{array}$ & $\begin{array}{l}\text { EO }(25,50 \text {, } \\
75 \mathrm{mg} / \mathrm{kg}) \text { has } \\
\text { produced significant } \\
\text { and dose-dependent } \\
\text { inhibition of writhes } \\
\text { and also of thermal } \\
\text { hyperalgesia at the } \\
\text { doses of } 50 \text { and } \\
75 \mathrm{mg} / \mathrm{kg}(n=6)\end{array}$ & $\begin{array}{l}\text { Pentazocine has been used } \\
\text { as positive control. No } \\
\text { conflict of interest } \\
\text { statement }\end{array}$ \\
\hline $\begin{array}{l}\text { Nogueira et al. } \\
(2015)\end{array}$ & $\begin{array}{l}\text { Croton cordiifolius baill. } \\
\text { (Euphorbiaceae) [1,8-cineol } \\
\text { (25.09\%), } \alpha \text {-phellandrene } \\
(15.43 \%), \beta \text {-cymene (8.02\%), } \\
\text { spathulenol }(6.68 \%) \text { and } \\
\beta \text {-caryophyllene }(6.58 \%)]\end{array}$ & i.p & $\begin{array}{l}\text { Vehicle } \\
\text { (polyethoxylated } \\
\text { castor oil - } \\
\text { cremophor) }\end{array}$ & $\begin{array}{l}\text { Swiss } \\
\text { mice }\end{array}$ & $\begin{array}{l}\text { 1) Acetic acid } \\
\text { test; 2) } \\
\text { formalin test; } \\
\text { 3) capsaicin } \\
\text { test; 4) } \\
\text { glutamate } \\
\text { test }\end{array}$ & $\begin{array}{l}\text { EO ( } 50 \text { and } \\
100 \text { mg/kg) has } \\
\text { proven analgesia in all } \\
\text { tests ( } n=8 \text { ) apart } \\
\text { from capsaicin, } \\
\text { comparable to } \\
\text { indomethacin in its } \\
\text { highest dose (acetic } \\
\text { acid test) and higher } \\
\text { than morphine } \\
\text { (formalin test; in the } \\
\text { second phase only at } \\
\text { the highest dose). In } \\
\text { gluatamate test only } \\
\text { the highest dose has } \\
\text { been effective. This } \\
\text { effect id independent } \\
\text { on naloxone }\end{array}$ & $\begin{array}{l}\text { Indomethacin and } \\
\text { morphine have been used } \\
\text { as positive control and } \\
\text { naloxone as antagonist. } \\
\text { Declaration of no conflict of } \\
\text { interest }\end{array}$ \\
\hline Park et al. (2015) & 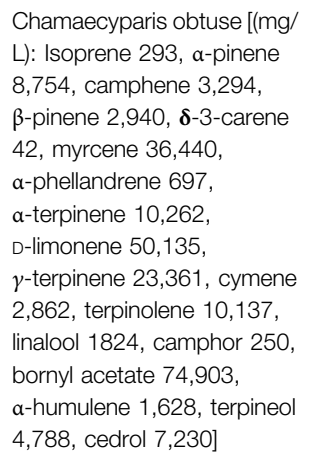 & i.p & $\begin{array}{l}\text { Control (distilled } \\
\text { water containing } \\
0.5 \% \text { DMSO } \\
\text { instead of } \\
\text { treatments) }\end{array}$ & $\begin{array}{l}\text { C57BL/ } \\
\text { 6J mice }\end{array}$ & $\begin{array}{l}\text { 1) Formalin } \\
\text { test, 2) acetic } \\
\text { acid test, 3) } \\
\text { hot-plate } \\
\text { test and }\end{array}$ & $\begin{array}{l}\text { EO ( } 5 \text { and } 10 \mathrm{mg} / \mathrm{kg} \text { ) } \\
\text { is effective in } 1) \\
\text { formalin test (only at } \\
\text { the lowest dose in the } \\
\text { first phase) }(n=7-8) \\
\text { and in the } 2 \text { ) acetic } \\
\text { acid test ( } n=7-8) \text {, not } \\
\text { in the hot-plate test } \\
(n=10)\end{array}$ & $\begin{array}{l}\text { Acetylsalicylic acid has } \\
\text { been used as positive } \\
\text { control. No conflict of } \\
\text { interest statement }\end{array}$ \\
\hline Queiroz et al. (2014) & $\begin{array}{l}\text { Xylopia laevigata (annonaceae) } \\
\text { [ } \gamma \text {-muurolene }(17.78 \%), \\
\delta \text {-cadinene }(12.23 \%), \\
\text { bicyclogermacrene }(7.77 \%), \\
\text { a-copaene }(7.17 \%), \\
\text { germacrene D }(6.54 \%), \\
\text { (E)-caryophyllene }(5.87 \%), \\
\gamma \text {-cadinene }(4.72 \%), \\
\text { aromadendrene }(4.66 \%), \text { and } \\
\gamma \text {-amomhene }(4.39 \%)]\end{array}$ & i.p & $\begin{array}{l}\text { Vehicle (saline }+2 \\
\text { drops of tween } \\
800.2 \% \text { ) }\end{array}$ & $\begin{array}{l}\text { Swiss } \\
\text { albino } \\
\text { mice }\end{array}$ & $\begin{array}{l}\text { 1) Acetic acid } \\
\text { test; 2) } \\
\text { formalin test }\end{array}$ & $\begin{array}{l}\text { EO }(12.5,25, \\
50 \mathrm{mg} / \mathrm{kg}) \text { has } \\
\text { significantly reduced } \\
\text { the } 1) \text { acetic acid- } \\
\text { induced writhings- } \\
\text { induced nociception } \\
(n=8) \text { and the } 2) \text { two } \\
\text { phases of the formalin } \\
\text { test }(n=8)\end{array}$ & $\begin{array}{l}\text { Mice have been used only } \\
\text { once. Morphine has been } \\
\text { used as References drug. } \\
\text { Naloxone has been used as } \\
\text { antagonist. Declaration of } \\
\text { no conflict of interest }\end{array}$ \\
\hline
\end{tabular}

(Continued on following page) 
TABLE 1 | (Continued) Main characteristics of the studies included showing the efficacy of EOs in nociceptive models.

\begin{tabular}{|c|c|c|c|c|c|c|c|}
\hline Study & $\begin{array}{c}\text { EO [most representative } \\
\text { components] }\end{array}$ & $\begin{array}{c}\text { Route of } \\
\text { administration }\end{array}$ & Control & $\begin{array}{l}\text { Mice } \\
\text { strain }\end{array}$ & Pain model & $\begin{array}{c}\text { Analgesic outcome } \\
\text { and } \\
\text { sample size }\end{array}$ & Design \\
\hline $\begin{array}{l}\text { Sakurada et al. } \\
\text { (2011) }\end{array}$ & $\begin{array}{l}\text { Bergamot (citrus bergamia } \\
\text { risso) [0.38\% D-limonene, } \\
70.26 \% \text { linalyl acetate, } \\
18.95 \% \text { linalool, } 0.62 \% \\
\gamma \text {-terpinene and } 0.03 \% \\
\beta \text {-pinene] }\end{array}$ & S.C & $\begin{array}{l}\text { Saline, jojoba wax } \\
\text { and none }\end{array}$ & $\begin{array}{l}\text { ddy } \\
\text { mice }\end{array}$ & $\begin{array}{l}\text { Capsaicin } \\
\text { test }\end{array}$ & $\begin{array}{l}\text { Dose-dependent } \\
\text { inhibiton of } \\
\text { nociceptive response } \\
\text { by the EO }(2.5,5,10 \text {, } \\
20 \mu \mathrm{g} / \mathrm{paw}) \\
\text { significant only at the } \\
\text { highest doses of } 10 \\
\text { and } 20 \mu \mathrm{g} / \mathrm{paw} \\
(n=10)\end{array}$ & $\begin{array}{l}\text { Mice have been tested in } \\
\text { randomized order and } \\
\text { behavioral experiments } \\
\text { have been performed } \\
\text { during the light period } \\
\text { between 10:00 and } \\
\text { 17:00h. Lidocaine } \\
\text { hydrochloride } \\
\text { monohydrate and } \\
\text { morphine hydrochloride } \\
\text { have been used as } \\
\text { References drugs. } \\
\text { Naloxone hydrochloride } \\
\text { and methiodide have been } \\
\text { used as antagonists. No } \\
\text { conflict of interest } \\
\text { statement }\end{array}$ \\
\hline Sharif et al. (2020) & $\begin{array}{l}\text { Tanacetum balsamita } \\
\text { (compositae) [carvone } \\
\text { (39.8\%) and } \\
\text { a-thujone (11.9\%).]. }\end{array}$ & i.p & $\begin{array}{l}\text { Vehicle } \\
\text { (sweet almond oil) }\end{array}$ & $\begin{array}{l}\text { NMRI } \\
\text { mice }\end{array}$ & Hot-plate test & $\begin{array}{l}\text { EO produced anti- } \\
\text { nociception only at } \\
\text { the dose of } 100 \text {, } \\
\mathrm{mg} / \mathrm{kg})(n=6-8)\end{array}$ & $\begin{array}{l}\text { Experiments have been } \\
\text { conducted between } \\
10.00 \text { a.m. and } 13.00 \text { p.m. } \\
\text { and mice used only once. } \\
\text { Morphine has been used } \\
\text { as positive control. No } \\
\text { conflict of interest } \\
\text { statement }\end{array}$ \\
\hline $\begin{array}{l}\text { Ulku } \\
\text { Karabay-Yavasoglu } \\
\text { et al. (2006) }\end{array}$ & $\begin{array}{l}\text { Satureja thymbra L. } \\
\text { (lamiaceae) [ } \gamma \text {-terpinene } \\
(40.99 \%) \text {, carvacrol } \\
(17.50 \%) \text {, thymol }(13.19 \%) \text {, } \\
\text { and P-cymene }(12.73 \%), \\
\beta \text {-caryophyllene }(3.15 \%) \text {, } \\
\text { a-thujene (1.98\%), and } \\
\text { thymylmethylether (1.94\%)] }\end{array}$ & i.p & $\begin{array}{l}\text { Vehicle }(2 \% \\
\text { tween } 20)\end{array}$ & $\begin{array}{l}\text { Albino } \\
\text { mice }\end{array}$ & Formalin test & $\begin{array}{l}\text { Analgesic effect in the } \\
\text { early }(50 \text { and } \\
100 \mathrm{mg} / \mathrm{kg}) \text { and in } \\
\text { the late }(25,50 \text {, and } \\
100 \mathrm{mg} / \mathrm{kg}) \text { phases } \\
\text { of the formalin test } \\
(n=10)\end{array}$ & $\begin{array}{l}\text { Animals were used } \\
\text { only once and humanly } \\
\text { sacrificed at the end of } \\
\text { the test. Morphine has } \\
\text { been used as References } \\
\text { drug and naloxone as } \\
\text { antagonist. No conflict of } \\
\text { interest statement }\end{array}$ \\
\hline $\begin{array}{l}\text { Venãncio et al. } \\
\text { (2011) }\end{array}$ & $\begin{array}{l}\text { Ocimum basilicum L. } \\
\text { (lamiaceae) [linalool } \\
\text { (76.13\%), geraniol (11.16\%), } \\
\text { 1,8-cineol }(6.66 \%)]\end{array}$ & i.p & $\begin{array}{l}\text { Vehicle (saline + } \\
\text { tween } 800.2 \% \text { ) }\end{array}$ & $\begin{array}{l}\text { Swiss } \\
\text { mice }\end{array}$ & $\begin{array}{l}\text { Orofacial } \\
\text { formalin, } \\
\text { glutamate } \\
\text { and } \\
\text { capsaicin- } \\
\text { induced } \\
\text { nociception }\end{array}$ & $\begin{array}{l}\text { EO }(50,100, \\
200 \mathrm{mg} / \mathrm{kg}) \text { is } \\
\text { effective in all the } \\
\text { doses at the highest } \\
\text { doses }(n=8)\end{array}$ & $\begin{array}{l}\text { Mice have been used } \\
\text { once in the study. } \\
\text { Nociception tests have } \\
\text { been conducted by the } \\
\text { same observer. Morphine } \\
\text { hydrochloride and lidocaine } \\
\text { have been used as } \\
\text { References drugs. No } \\
\text { conflict of interest } \\
\text { statement }\end{array}$ \\
\hline Zarei et al. (2018) & $\begin{array}{l}\text { Inula britannica L. } \\
\text { (asteraceae) [viridiflorol } \\
(7.17 \%-8.20 \%) \text { and } \\
\text { himachalol (3.45\%-8.71\%) } \\
\text { followed by } 6,10,14- \\
\text { trimethyl-2-pentadecanone } \\
(5.43 \%-2.95 \%), 13- \\
\text { tetradecanolide } \\
(3.93 \%-4.87 \%) \text { and 3- } \\
\text { methyl-4-propyl-2,5- } \\
\text { furandione (4.06\%-0.29\%) } \\
\text { Todorova et al. (2017)]. } \\
\text { Flowers of inula britannica }\end{array}$ & i.p & Control (saline) & $\begin{array}{l}\text { Swiss } \\
\text { albino } \\
\text { mice }\end{array}$ & $\begin{array}{l}\text { 1) tail-flick } \\
\text { test; 2) acetic } \\
\text { acid test; 3) } \\
\text { formalin test } \\
\text { and 4) } \\
\text { glutamate- } \\
\text { test }\end{array}$ & $\begin{array}{l}\text { EO }(25,50, \text { and } \\
100 \mathrm{mg} / \mathrm{kg})(n=5) \text { for } \\
\text { all tests. } 1) \text { the highest } \\
\text { dose has resulted } \\
\text { effective; } 2) \text { the doses } \\
\text { of } 50 \text { and } 100 \mathrm{mg} / \mathrm{kg} \\
\text { have been effective; } \\
\text { 3) the highest dose is } \\
\text { comparable to } \\
\text { morphine; 4) only the } \\
\text { highest dose is } \\
\text { significantly active }\end{array}$ & $\begin{array}{l}\text { Experiments have been } \\
\text { carried out between } 8 \text { a.m. } \\
\text { and } 12 \text { p.m. Morphine, } \\
\text { naloxone, L-Arginine, } \\
\text { methylene blue, } \\
\text { glibenclamide, } \\
\text { naltrindole, nor- } \\
\text { binaltorphimine and } \\
\text { naloxonazine have been } \\
\text { used as positive and } \\
\text { negative controls. } \\
\text { Declaration of no conflict } \\
\text { of interest }\end{array}$ \\
\hline
\end{tabular}

(Continued on following page) 
TABLE 1 | (Continued) Main characteristics of the studies included showing the efficacy of EOs in nociceptive models.

\begin{tabular}{|c|c|c|c|c|c|c|c|}
\hline Study & $\begin{array}{c}\text { EO [most representative } \\
\text { components] }\end{array}$ & $\begin{array}{c}\text { Route of } \\
\text { administration }\end{array}$ & Control & $\begin{array}{l}\text { Mice } \\
\text { strain }\end{array}$ & Pain model & $\begin{array}{c}\text { Analgesic outcome } \\
\text { and } \\
\text { sample size }\end{array}$ & Design \\
\hline $\begin{array}{l}\text { Zendehdel et al. } \\
\text { (2015) }\end{array}$ & $\begin{array}{l}\text { Bunium persicum (boiss.) } \\
\text { [germacrene-d (22.1-24.1\%) } \\
\text { and E-caryophyllene } \\
(26.6-38 \%) \text { Sofi et al. } \\
\text { (2009)]. Samples of the plant } \\
\text { identified at the division of } \\
\text { pharmacognosy, faculty of } \\
\text { pharmacy, tehran university } \\
\text { of medical sciences, Iran }\end{array}$ & i.p & $\begin{array}{l}\text { Control (Tween- } \\
80(0.5 \%)\end{array}$ & $\begin{array}{l}\text { Albino } \\
\text { NMRI } \\
\text { mice }\end{array}$ & $\begin{array}{l}\text { Acetic acid } \\
\text { test }\end{array}$ & $\begin{array}{l}\text { EO }(0.001,0.01 \text {, } \\
0.05,0.1,0.5 \text { and } \\
1 \% ; 10 \mathrm{ml} / \mathrm{kg})(n=7) \text {. } \\
\text { The EO } 0.01 \% \text { has } \\
\text { significantly reduced } \\
\text { contortions ( } 90.7 \% \\
\text { vs } 38.13 \% \text { of } \\
\text { indomethacin) and } \\
\text { this effect has been } \\
\text { inhibited by naloxone } \\
\text { and reduced by } \\
\text { chlorpheniramine and } \\
\text { cimetidine }\end{array}$ & $\begin{array}{l}\text { Experiments have been } \\
\text { conducted during the light } \\
\text { phase (10:00-17:00 h). } \\
\text { Antagonism studies have } \\
\text { been performed using } \\
\text { naloxone, the serotonergic } \\
\text { receptor antagonist } \\
\text { cyproheptadine, the } \\
\text { histamine H1-receptor } \\
\text { antagonist } \\
\text { chlorpheniramineand the } \\
\text { histamine H2-receptor } \\
\text { antagonist cimetidine. } \\
\text { Indomethacin has been } \\
\text { used as References drug. } \\
\text { No conflict of interest } \\
\text { statement }\end{array}$ \\
\hline
\end{tabular}

Studies characteristics in response to PICOS (participants/population, interventions, comparisons, outcomes, and study design) question for records including acute nociceptive pain models; $\mathrm{n}=$ number of animals. The order of references in the table follows that in the text.

morphine, of which the EO of bergamot enhances the activity (Kuwahata et al., 2013), and it was reversed by naloxone methiodide, peripherally $\mu$-opioid receptor preferring antagonist, $\beta$-funaltrexamine hydrochloride, selective $\mu$-opioid receptor antagonist, and $\beta$-endorphin antiserum, but not by the non-selective $\delta$-opioid receptor antagonist naltrindole and by the selective $\kappa$-opioid receptor antagonist nor-binaltorphimine. Importantly, the study by Hamamura et al. (2020) in which the EO of bergamot was administered s. c. with an osmotic pump to allow a continuous delivery devoid of smell during PSNL, demonstrated that the antiallodynic effect of this EO is systemic and does not depend on olfactory stimulation. In this study (Hamamura et al., 2020) the increase of planar activity during the light period induced by PSNL, with the maximum effect at the seventh postoperative day and like allodynia, was shown to be abolished by continuously administered EO. This effect is antagonized by naloxone hydrochloride. Observation lasting 14 days with a theoretical duration of the osmotic pump of one week can mimic administration during chronic pain. The main features of the studies on EOs anti-allodyinic properties are summarized in Table 2.

\subsection{Risk of Bias Assessment}

The studies included in the qualitative analysis were assessed for methodological quality according to the SYRCLE's RoB tool (Hooijmans et al., 2014) and the CAMARADES checklist (Macleod et al., 2004; Hooijmans et al., 2014; Suokas et al., 2014), based on the Cochrane RoB (Sterne et al., 2019). These items comprise all the possible forms of bias. 1) Selection bias-sequence generation (allocation sequence able to produce comparable groups). 2) Selection bias-baseline characteristics (comparable and not adjusted for confounders in the analysis). 3) Selection bias-allocation concealment (during the enrollment). 4) Performance bias-random housing and randomization during the study. 5) Performance bias-blinding of investigators during the study. 6) Detection bias-random outcome assessment. 7) Detection bias-blinding of outcome assessors. 8) Attrition bias (animals eventually excluded from outcome assessment). 9) Reporting bias-reports free of selective outcome reporting. Finally, 10) other sources of bias: lack of evidence of induced pain using the selected behavioral outcome measure before EO administration and examination (i.e., sham procedure), clear description of methods with number of animals used, attention to circadian regulation for behavioral studies, use of the same observer for behavioral tests, use of control and positive and negative control drugs, sample size calculation, statement of conflict of interest, statement of compliance with animal welfare regulations and attention to ethics.

In terms of the two items regarding selection bias, no study reported the method of allocation and, even though they conducted baseline measures, none of the studies describe how experimental groups were composed to ensure homogeneity and consistency. Only the study by Lima and collaborators (Lima et al., 2012) in which mice with baseline latencies of more than $10 \mathrm{~s}$, and studies by de Oliveira Júnior and colleagues (de Oliveira Júnior et al., 2017; de Oliveira et al., 2018) of more than 20 s, at the hot-plate were excluded from the experiments.

As reported in Table 1, five studies (Guimaraes et al., 2009; Andrade et al., 2012; Lima et al., 2012; de Oliveira Júnior et al., 2017; de Oliveira et al., 2018) adopted random housing of mice. The paper by Khodabakhsh et al. reported no randomization of mice but only of rats, which are not included in this systematic review and meta-analysis (Khodabakhsh et al., 2015). Mice were tested in a randomized order in studies by Sakurada and collaborators and Katsuyama et al., 2015 (Sakurada et al., 2011; Katsuyama et al., 2015). In the study by Bae et al. (2020) mice were randomly assigned to groups. The study by Khalid et al. (2011) used a blind, randomized design. Mice were randomly assigned to groups and experiments were performed in a blind manner in the study by Quintans and coworkers (Quintans et al., 2017). 
TABLE 2 | Main characteristics of the studies included showing efficacy of EOs in neuropathic models.

\begin{tabular}{|c|c|c|c|c|c|c|c|}
\hline Study & EO & $\begin{array}{c}\text { Route of } \\
\text { administration }\end{array}$ & Control & $\begin{array}{l}\text { Mice } \\
\text { strain }\end{array}$ & $\begin{array}{l}\text { Pain } \\
\text { model }\end{array}$ & $\begin{array}{l}\text { Analgesic outcome and } \\
\text { sample size }\end{array}$ & Design \\
\hline $\begin{array}{l}\text { Hamamura } \\
\text { et al. (2020) }\end{array}$ & $\begin{array}{l}\text { Bergamot (citrus bergamia } \\
\text { risso) [D-limonene }(39.60 \%) \text {, } \\
\text { linalyl acetate }(31.09 \%) \text {, and } \\
\text { linalool }(9.55 \%)]\end{array}$ & $\begin{array}{l}\text { s.c., with the aid of } \\
\text { an osmotic pump }\end{array}$ & $\begin{array}{l}\text { Jojoba } \\
\text { wax }\end{array}$ & $\begin{array}{l}\text { ddY } \\
\text { mice }\end{array}$ & $\begin{array}{l}\text { Partial } \\
\text { sciatic } \\
\text { nerve } \\
\text { ligation }\end{array}$ & $\begin{array}{l}\text { Reduction of the induced } \\
\text { increase of planar activity } \\
\text { during the light period at the } \\
\text { 7th post-operative day } \\
\text { (control } n=6 \text {; EO } \mathrm{n}=9 \text { ) }\end{array}$ & $\begin{array}{l}\text { Acclimatization to the lighting } \\
\text { conditions for } 1 \text { week. After } \\
\text { basal measures before surgery, } \\
\text { the mice have been observed for } \\
14 \text { days. Antagonism study with } \\
\text { naloxone hydrochloride. } \\
\text { Declaration of no conflict of } \\
\text { interest. Sham procedure }\end{array}$ \\
\hline $\begin{array}{l}\text { Komatsu } \\
\text { et al. (2018) }\end{array}$ & $\begin{array}{l}\text { Bergamot (citrus bergamia } \\
\text { risso) [0.38\% D-limonene, } \\
70.26 \% \text { linalyl acetate, } \\
18.95 \% \text { linalool, } 0.62 \% \\
\gamma \text {-terpinene, and } 0.03 \% \text { of } \\
\beta \text {-pinene] }\end{array}$ & S.C & $\begin{array}{l}\text { Jojoba } \\
\text { wax and } \\
\text { saline }\end{array}$ & $\begin{array}{l}\text { ddY } \\
\text { mice }\end{array}$ & $\begin{array}{l}\text { Partial } \\
\text { sciatic } \\
\text { nerve } \\
\text { ligation }\end{array}$ & $\begin{array}{l}\text { On post-operative day } 7 \text {, the } \\
\text { EO of bergamot }(5.0,10.0 \text {, } \\
\text { and } 20.0 \mu \mathrm{g} / \mathrm{paw} \text { ) has } \\
\text { attenuated dose- } \\
\text { dependently mechanical } \\
\text { allodynia, significantly at the } \\
\text { dose of } 20.0 \mu \mathrm{g} / \text { paw }(n=10)\end{array}$ & $\begin{array}{l}\text { Antagonism studies with } \\
\text { naloxone methiodide ( } \mu \text {-opioid } \\
\text { receptor preferring antagonist), } \\
\beta \text {-funaltrexamine hydrochloride } \\
\text { (selective } \mu \text {-opioid receptor } \\
\text { antagonist), } \beta \text {-endorphin } \\
\text { antiserum, naltrindole (non- } \\
\text { selective } \delta \text {-opioid receptor } \\
\text { antagonist) and nor- } \\
\text { binaltorphimine (selective } \\
\kappa \text {-opioid receptor antagonist). } \\
\text { Behavioral tests have been } \\
\text { performed between 10:00 and } \\
16: 00 \text { h and for } 2 \text { days before } \\
\text { the start of the experiment for } \\
\text { acclimatation of the mice to the } \\
\text { testing procedures. Sham } \\
\text { procedure. No conflict of interest } \\
\text { statement }\end{array}$ \\
\hline $\begin{array}{l}\text { Kuwahata } \\
\text { et al. (2013) }\end{array}$ & $\begin{array}{l}\text { Bergamot (citrus bergamia } \\
\text { risso) }[0.38 \% \text { of D-limonene, } \\
70.26 \% \text { of linalyl acetate, } \\
18.95 \% \text { of linalool, } 0.62 \% \text { of } \\
\gamma \text {-terpinene, and } 0.03 \% \text { of } \\
\beta \text {-pinene] }\end{array}$ & S.C & $\begin{array}{l}\text { Jojoba } \\
\text { wax + } \\
\text { saline }\end{array}$ & $\begin{array}{l}\text { ddY } \\
\text { mice }\end{array}$ & $\begin{array}{l}\text { Partial } \\
\text { sciatic } \\
\text { nerve } \\
\text { ligation }\end{array}$ & $\begin{array}{l}\text { Dose-dependent reduction } \\
(5,10,20 \mu \mathrm{g}) \text { of tactile } \\
\text { allodynia } 7 \text { days after surgery } \\
(n=10)\end{array}$ & $\begin{array}{l}\text { Behavioral experiments have } \\
\text { been carried out from 10:00 a.m. } \\
\text { to 6:00 p.m. and mice have been } \\
\text { used only once. Morphine } \\
\text { hydrochloride has been used as } \\
\text { References drug. Sham } \\
\text { procedure. No conflict of interest } \\
\text { statement }\end{array}$ \\
\hline
\end{tabular}

Studies characteristics relative to PICOS (participants/population, interventions, comparisons, outcomes, and study design) question for retrieved records about neuropathic pain models; $\mathrm{n}=$ number of animals. The order of references in the table follows that in the text.

Moreover, in the study by Ximenes et al. (2013), the observation was conducted by a blind observer, but the number of animals used for behavioral testing was not reported, only for histological assays. Otherwise, the number of animals per group was reported, but studies that provided a range and not an exact number were not considered eligible for quantitative analysis. Attrition and reporting biases cannot be assessed from the full text of the included studies. Importantly, sham procedure and the certainty of exact execution of the pain model is present only in studies on allodynia, i.e., the studies by Hamamura et al. (2020), Komatsu et al. (2018a), and Kuwahata et al. (2013).

Attention to the circadian rhythm in behavioral testing was reported by the following studies: (Andrade et al., 2012; Quintans et al., 2017; Guimaraes et al., 2009; Halder et al., 2012; Katsuyama et al., 2015; Khodabakhsh et al., 2015; Miraghazadeh et al., 2015; Sakurada et al., 2011; Sharif et al., 2020; Zarei et al., 2018; Zendehdel et al., 2015; Komatsu et al., 2018b; Kuwahata et al., 2013). All the studies used control and positive and negative modulators. Importantly, multiple controls were used in the following studies (Katsuyama et al., 2015; Komatsu et al., 2018b; Kuwahata et al., 2013; Sakurada et al., 2011). Behavioral testing was conducted by the same observers in the following studies (de Oliveira Júnior et al., 2017; de Oliveira et al., 2018; Venãncio et al., 2011). Sample size calculation was not reported and the conflict of interest statement is present only in eight studies (Queiroz et al., 2014; Nogueira et al., 2015; de Oliveira Júnior et al., 2017; de Oliveira et al., 2018; Jahandar et al., 2018; Zarei et al., 2018; Lee et al., 2019; Hamamura et al., 2020). This could be due to the lack of requirement of these aspects in journals in the last few years. A statement of compliance with animal welfare regulations is reported in all the studies since it is an inclusion criterion. Moreover, six studies (Ulku Karabay-Yavasoglu et al., 2006; Venâncio et al., 2011; Queiroz et al., 2014; Khodabakhsh et al., 2015; Miraghazadeh et al., 2015; Sharif et al., 2020) also stated that they used each mouse only once, thus proving particular attention to animal welfare. Importantly, only the study by Hamamura et al. (2020) reported acclimatization to lighting conditions for one week and that an observation period of 14 days can model examination during chronic pain. 


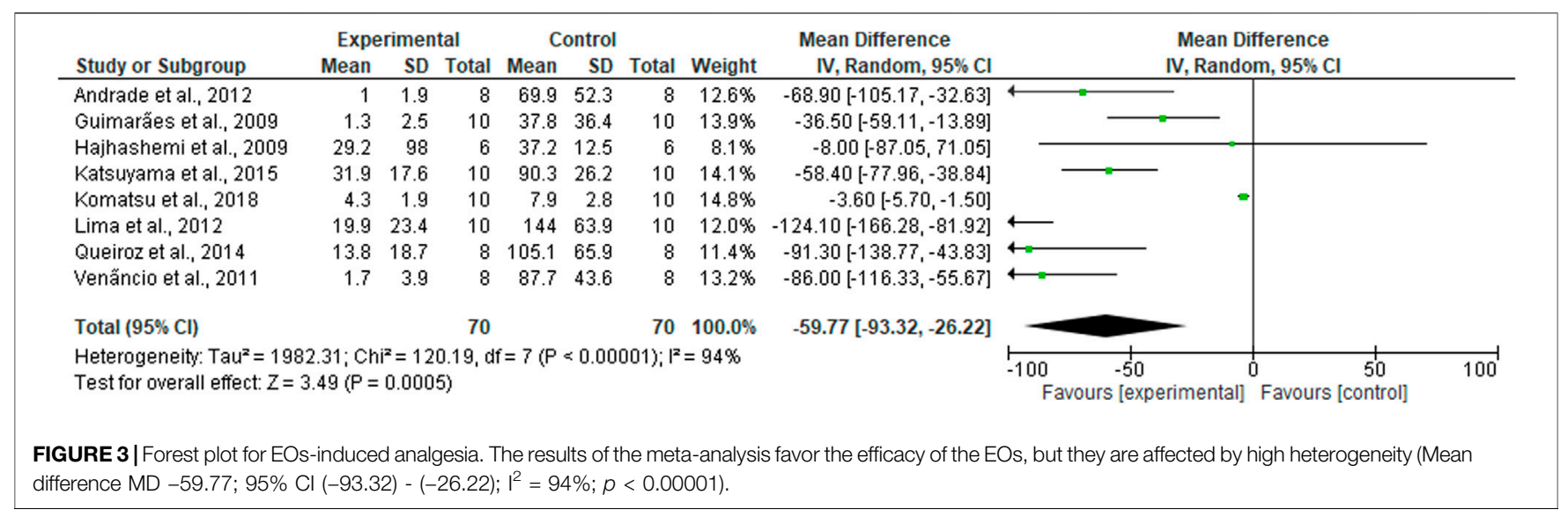

\subsection{Meta-Analysis}

This meta-analysis comprises eight studies for a total of 140 mice. The studies were considered comparable when the analgesic outcome was expressed as mean \pm standard error of the mean (SEM) since these measures could be converted for meta-analysis in mean and standard deviation (SD). Moreover, only studies reporting the exact number of animals per group were included in quantitative analysis. Studies investigating the same pain model were considered. The formalin test pain model was chosen since it provides a biphasic nociceptive response. Due to the sensitization processes occurring during the second phase, the study on mechanical allodynia expressed has been included (Komatsu et al., 2018b). The results of the forest plot favor the analgesic efficacy of EO (Mean difference MD -59.77; 95\% CI (-93.32) (-26.22); $\mathrm{I}^{2}=94 \% ; p<0.00001$; Figure 3), but need to be carefully examined because of the extremely high heterogeneity, which is also confirmed by the asymmetry of the funnel plot analysis standing for high risk of publication bias, small studies and high differences in study precision.

\section{DISCUSSION}

Interest in the use of EOs and aromatherapy has been continuously growing during the last few decades in parallel with preclinical research. However, in spite of all this effort of preclinical research, it is necessary to establish whether there is a strong rationale for the clinical use of EOs. This issue is even more controversial in the field of pain relief since the use of aromatherapy could reduce the dose of painkillers endowed with serious side effects, particularly in under studied areas of neuropathic pain, like opioids (Morrone et al., 2017; Scuteri et al., 2020b). Alternative pain treatments could increase time in treatment before the loss of efficacy. This is relevant to fragile populations, e.g., patients suffering from dementia, who are often undertreated compared to cognitively intact counterparts, more so during the Sars-CoV2 pandemic (Scuteri et al., 2020c).

This systematic review and meta-analysis assesses the efficacy of EOs in preclinical models of acute inflammatory nociception and neuropathic pain to understand if there is a rational basis for clinical translation. Several EOs from multiple families were found to be efficacious, in particular, croton and bergamot EOs have been extensively studied. It is noteworthy that 27 out of the 30 studies included in the qualitative analysis were only performed on acute pain models like writhings and the hot plate test. These tests are very useful since they are easy to conduct and provide fast results, but they do not resemble clinical pain conditions. Taking this into account, the quantitative analysis only includes studies on formalin test, which is more similar to clinical conditions due to its biphasic nature, and the only study on mechanical allodynia that could compare to the other seven included.

All these studies included in this review have a different experimental design and most of them present serious concerns in terms of selection, performance, and detection biases. Most studies do not adhere to the guidelines for Animal Research: Reporting In Vivo Experiments (ARRIVE), which are fundamental for accurate in vivo preclinical research (Rice et al., 2013). Another methodological aspect responsible for bias in the meta-analysis is that control groups were often used in more than one experiment, and studies including multiple comparisons can introduce errors. Thus, this systematic review and meta-analysis points to the importance of appropriate in vivo modeling to enhance the translational impact of pain research. Future research is necessary to improve the methodological quality and homogeneity of studies.

The results of the meta-analysis highlighted the efficacy of EOs in preclinical pain, but these data are downgraded due to the high heterogeneity of the studies. In particular, the analyzed EOs present the analgesic efficacy required by the recommendations of the Initiative on Methods, Measurement, and Pain Assessment in Clinical Trials (IMMPACT) (Turk et al., 2003), according to which a decrease in pain is defined as clinically meaningful if it accounts for a $30 \%$ to $36 \%$ reduction. However, this is referred to chronic pain and this systematic review and meta-analysis have found that only the EO of bergamot had proven efficacy both in nociceptive and in neuropathic pain models. Moreover, it was also studied for 14 days, an experimental setting suitable for modeling chronic pain (Hamamura et al., 2020). 
Another important issue is that the consolidated data come from hypothesis-generating completely original preclinical studies and that they are then confirmed by hypothesis-driven studies (Mikolajewicz and Komarova, 2019). In this case, the EO of bergamot was confirmed to have strong analgesic properties in some of the most used and reliable models of inflammatory pain, i.e., formalin and capsaicin test in different experiments, sharing with most EO mechanisms involving opioid neurotransmission, and also in the PSNL. To the best of our knowledge, this is the first meta-analysis of preclinical studies on the analgesic effects of EOs and its working hypothesis was verified for bergamot EO, which could represent an important pharmacological tool for pain management in clinical settings. Along with clinical translations, more efforts are required to standardize in vivo preclinical studies in the field of pain research to allow for consistent research able to elucidate the mechanisms responsible for the analgesic properties of EOs.

\section{REFERENCES}

Abuhamdah, S., Huang, L., Elliott, M. S., Howes, M. J., Ballard, C., Holmes, C., et al. (2008). Pharmacological profile of an essential oil derived from Melissa officinalis with anti-agitation properties: focus on ligand-gated channels. J. Pharm. Pharmacol. 60 (3), 377-384. doi:10.1211/jpp.60.3. 0014

Achterberg, W., Lautenbacher, S., Husebo, B., Erdal, A., and Herr, K. (2020). Pain in dementia. Pain Rep. 5, e803. doi:10.1097/PR9.0000000000000803

Adam, B., Liebregts, T., Best, J., Bechmann, L., Lackner, C., Neumann, J., et al. (2006). A combination of peppermint oil and caraway oil attenuates the postinflammatory visceral hyperalgesia in a rat model. Scand. J. Gastroenterol. 41 (2), 155-160. doi:10.1080/00365520500206442

Ali, T., Javan, M., Sonboli, A., and Semnanian, S. (2012). Evaluation of the antinociceptive and anti-inflammatory effects of essential oil of Nepeta pogonosperma Jamzad et Assadi in rats. Daru 20, 48. doi:10.1186/2008-2231-20-48

Anaya-Eugenio, G. D., Rivero-Cruz, I., Bye, R., Linares, E., and Mata, R. (2016). Antinociceptive activity of the essential oil from Artemisia ludoviciana. J. Ethnopharmacol 179, 403-411. doi:10.1016/j.jep.2016.01.008

Andrade, G. S., Guimaraes, A. G., Santana, M. T., Siqueira, R. S., Passos, L. O., Machado, S. M. F., et al. (2012). Phytochemical screening, antinociceptive and anti-inflammatory effects of the essential oil of Myrcia pubiflora in mice. Revista Brasileira De Farmacognosia 22 (1), 181-188. doi:10.1590/s0102695x2011005000205

Awad, R., Muhammad, A., Durst, T., Trudeau, V. L., and Arnason, J. T. (2009). Bioassay-guided fractionation of lemon balm (Melissa officinalis L.) using an in vitro measure of GABA transaminase activity. Phytother Res. 23 (8), 1075-1081. doi:10.1002/ptr.2712

Bae, A. H., Kim, G., Seol, G. H., Lee, S. B., Lee, J. M., Chang, W., et al. (2020). Deltaand mu-opioid pathways are involved in the analgesic effect of Ocimum basilicum L in mice. J. Ethnopharmacol 250, 112471. doi:10.1016/j.jep. 2019.112471

Bagetta, G., Morrone, L. A., Rombolà, L., Amantea, D., Russo, R., Berliocchi, L., et al. (2010). Neuropharmacology of the essential oil of bergamot. Fitoterapia 81 (6), 453-461. doi:10.1016/j.fitote.2010.01.013

Ball, E. L., Owen-Booth, B., Gray, A., Shenkin, S. D., Hewitt, J., and McCleery, J. (2020). Aromatherapy for dementia. Cochrane Database Syst. Rev. 8, CD003150. doi:10.1002/14651858.CD003150.pub3

Belardo, C., Iannotta, M., Boccella, S., Rubino, R. C., Ricciardi, F., Infantino, R., et al. (2019). Oral cannabidiol prevents allodynia and neurological dysfunctions in a mouse model of mild traumatic brain injury. Front. Pharmacol. 10, 352. doi:10.3389/fphar.2019.00352

\section{DATA AVAILABILITY STATEMENT}

The original contributions presented in the study are included in the article.

\section{AUTHOR CONTRIBUTIONS}

DS, GB, TS, SS, and MTC. conceived the study. All Authors participated in preparation and read and approved the final manuscript.

\section{FUNDING}

DS is a post-doc recipient of a research grant salary as part of the research project (Tutor: GB) "Pharmacoepidemiology of drugs used in the treatment of neuropsychiatric symptoms and pain in people aged (over 65) with dementia" funded by Calabria Region (POR Calabria FESR-FSE 2014/2020-Linea B) Azione 10.5.12.

Boccella, S., Marabese, I., Guida, F., Luongo, L., Maione, S., and Palazzo, E. (2020). The modulation of pain by metabotropic glutamate receptors 7 and 8 in the dorsal striatum. Curr. Neuropharmacol. 18 (1), 34-50. doi:10.2174/ 1570159X17666190618121859

Chen, Y., Zhao, Y. Y., Wang, X. Y., Liu, J. T., Huang, L. Q., and Peng, C. S. (2011). [GC-MS analysis and analgesic activity of essential oil from fresh rhizoma of Cyperus rotundus]. Zhong Yao Cai 34 (8), 1225-1229.

Dastmalchi, K., Ollilainen, V., Lackman, P., Boije af Gennäs, G., Dorman, H. J., Järvinen, P. P., et al. (2009). Acetylcholinesterase inhibitory guided fractionation of Melissa officinalis L. Bioorg. Med. Chem. 17 (2), 867-871. doi:10.1016/j.bmc.2008.11.034

de Oliveira Júnior, R. G., Ferraz, C. A. A., Silva, J. C., de Oliveira, A. P., Diniz, T. C., E Silva, M. G., et al. (2017). Antinociceptive effect of the essential oil from Croton conduplicatus Kunth (euphorbiaceae). Molecules 22 (6), 900. doi:10. 3390/molecules22060900

de Oliveira, R. G., Ferraz, C. A. A., Silva, J. C., Teles, R. B. D., Silva, M. G., Diniz, T. C., et al. (2018). Neuropharmacological effects of essential oil from the leaves of Croton conduplicatus Kunth and possible mechanisms of action involved. J. Ethnopharmacology 221, 65-76. doi:10.1016/j.jep.2018.04.009

DerSimonian, R., and Kacker, R. (2007). Random-effects model for meta-analysis of clinical trials: an update. Contemp. Clin. Trials 28 (2), 105-114. doi:10.1016/j. cct.2006.04.004

Do Nascimento Silva, A., Bomfim, H. F., Magalhães, A. O., Da Rocha, M. L., and Lucchese, A. M. (2018). Chemical composition and antinociceptive activity of essential oil from myrcia rostrata dc. (myrtaceae) in animal models. Quimica Nova 41 (9), 982-988. doi:10.21577/0100-4042.20170274

Duval, S., and Tweedie, R. (2000). Trim and fill: a simple funnel-plot-based method of testing and adjusting for publication bias in meta-analysis. Biometrics 56 (2), 455-463. doi:10.1111/j.0006-341x.2000.00455.x

Editorial. (2016). Meta-analysis in basic biology. Nat. Methods 13 (12), 959. doi:10. 1038/nmeth.4102

Egger, M., Davey Smith, G., Schneider, M., and Minder, C. (1997). Bias in metaanalysis detected by a simple, graphical test. BMJ 315 (7109), 629-634. doi:10. 1136/bmj.315.7109.629

Evans, L. K. (1987). Sundown syndrome in institutionalized elderly. J. Am. Geriatr. Soc. 35 (2), 101-108. doi:10.1111/j.1532-5415.1987.tb01337.x

Guginski, G., Luiz, A. P., Silva, M. D., Massaro, M., Martins, D. F., Chaves, J., et al. (2009). Mechanisms involved in the antinociception caused by ethanolic extract obtained from the leaves of Melissa officinalis (lemon balm) in mice. Pharmacol. Biochem. Behav. 93 (1), 10-16. doi:10.1016/j.pbb.2009.03.014

Guimaraes, A. G., Melo, M. S., Bonfim, R. R., Passos, L. O., Machado, S. M. F., Ribeiro, A. D., et al. (2009). Antinociceptive and anti-inflammatory effects of the essential oil of Eugenia candolleana DC., Myrtaceae, on mice. Revista 
Brasileira De Farmacognosia 19 (4), 883-887. doi:10.1590/s0102$695 \times 2009000600016$

GVR (2020). Report No.: 978-1-68038-549-6. 1-153. Essential oils market size, share \& trends analysis report by application (food \& beverages, spa \& relaxation), by product (orange, peppermint), by sales channel, and segment forecasts, $2020-2027$.

Hajhashemi, V., Sajjadi, S. E., and Heshmati, M. (2009). Anti-inflammatory and analgesic properties of Heracleum persicum essential oil and hydroalcoholic extract in animal models. J. Ethnopharmacol 124 (3), 475-480. doi:10.1016/j. jep.2009.05.012

Halder, S., Mehta, A. K., Mediratta, P. K., and Sharma, K. K. (2012). Acute effect of essential oil of Eugenia caryophyllata on cognition and pain in mice. Naunyn Schmiedebergs Arch. Pharmacol. 385 (6), 587-593. doi:10.1007/s00210-012$0742-2$

Hamamura, K., Katsuyama, S., Komatsu, T., Scuteri, D., Bagetta, G., Aritake, K., et al. (2020). Behavioral effects of continuously administered bergamot essential oil on mice with partial sciatic nerve ligation. Front. Pharmacol. 11, 1310. doi:10.3389/fphar.2020.01310

Hamm, R. J., and Knisely, J. S. (1985). Environmentally induced analgesia: an agerelated decline in an endogenous opioid system. J. Gerontol. 40 (3), 268-274. doi:10.1093/geronj/40.3.268

Hayashi, T., Watanabe, C., Katsuyama, S., Agatsuma, Y., Scuteri, D., Bagetta, G., et al. (2020). Contribution of histamine to nociceptive behaviors induced by intrathecally administered cholecystokinin-8. Front. Pharmacol. 11, 590918. doi:10.3389/fphar.2020.590918

Higgins, J. P., and Thompson, S. G. (2002). Quantifying heterogeneity in a metaanalysis. Stat. Med. 21 (11), 1539-1558. doi:10.1002/sim.1186

Hooijmans, C. R., Rovers, M. M., de Vries, R. B., Leenaars, M., Ritskes-Hoitinga, M., and Langendam, M. W. (2014). SYRCLE's risk of bias tool for animal studies. BMC Med. Res. Methodol. 14 (1), 43. doi:10.1186/1471-2288-14-43

Husebo, B. S., Ballard, C., Sandvik, R., Nilsen, O. B., and Aarsland, D. (2011). Efficacy of treating pain to reduce behavioural disturbances in residents of nursing homes with dementia: cluster randomised clinical trial. BMJ 343, d4065. doi:10.1136/bmj.d4065

Jahandar, F., Asgarpanah, J., Najafizadeh, P., and Mousavi, Z. (2018). Antiinflammatory activity and chemical composition of Pycnocycla bashagardiana fruit's essential oil in animal models. Iran J. Basic Med. Sci. 21 (2), 188-193. doi:10.22038/ijbms.2017.20860.5426

Jun, Y. S., Kang, P., Min, S. S., Lee, J. M., Kim, H. K., and Seol, G. H. (2013). Effect of eucalyptus oil inhalation on pain and inflammatory responses after total knee replacement: a randomized clinical trial. Evid. Based Complement. Alternat Med. 2013, 502727. doi:10.1155/2013/502727

Katsuyama, S., Otowa, A., Kamio, S., Sato, K., Yagi, T., Kishikawa, Y., et al. (2015). Effect of plantar subcutaneous administration of bergamot essential oil and linalool on formalin-induced nociceptive behavior in mice. Biomed. Res. 36 (1), 47-54. doi:10.2220/biomedres.36.47

Khalid, M. H., Akhtar, M. N., Mohamad, A. S., Perimal, E. K., Akira, A., Israf, D. A., et al. (2011). Antinociceptive effect of the essential oil of Zingiber zerumbet in mice: possible mechanisms. J. Ethnopharmacol 137 (1), 345-351. doi:10.1016/j. jep.2011.05.043

Khodabakhsh, P., Shafaroodi, H., and Asgarpanah, J. (2015). Analgesic and antiinflammatory activities of Citrus aurantium L. blossoms essential oil (neroli): involvement of the nitric oxide/cyclic-guanosine monophosphate pathway. J. Nat. Med. 69 (3), 324-331. doi:10.1007/s11418-015-0896-6

Komatsu, T., Katsuyama, S., Uezono, Y., Sakurada, C., Tsuzuki, M., Hamamura, K., et al. (2018a). Possible involvement of the peripheral Mu-opioid system in antinociception induced by bergamot essential oil to allodynia after peripheral nerve injury. Neurosci. Lett. 686, 127-132. doi:10.1016/j.neulet.2018.08.053

Komatsu, T., Katsuyama, S., Uezono, Y., Sakurada, C., Tsuzuki, M., Hamamura, K., et al. (2018b). Possible involvement of the peripheral Mu-opioid system in antinociception induced by bergamot essential oil to allodynia after peripheral nerve injury. Neurosci. Lett. 686, 127-132. doi:10.1016/j.neulet.2018.08.053

Koyama, S., and Heinbockel, T. (2020). The effects of essential oils and terpenes in relation to their routes of intake and application. Int. J. Mol. Sci. 21 (5), 1558. doi:10.3390/ijms 21051558

Kusunose, N., Koyanagi, S., Hamamura, K., Matsunaga, N., Yoshida, M., Uchida, T., et al. (2010). Molecular basis for the dosing time-dependency of anti- allodynic effects of gabapentin in a mouse model of neuropathic pain. Mol. Pain 6, 83. doi:10.1186/1744-8069-6-83

Kuwahata, H., Komatsu, T., Katsuyama, S., Corasaniti, M. T., Bagetta, G., Sakurada, S., et al. (2013). Peripherally injected linalool and bergamot essential oil attenuate mechanical allodynia via inhibiting spinal ERK phosphorylation. Pharmacol. Biochem. Behav. 103 (4), 735-741. doi:10.1016/j.pbb.2012.11.003

Lakhan, S. E., Sheafer, H., and Tepper, D. (2016). The effectiveness of aromatherapy in reducing pain: a systematic review and meta-analysis. Pain Res. Treat. 2016, 8158693. doi:10.1155/2016/8158693

Lee, G., Park, J., Kim, M. S., Seol, G. H., and Min, S. S. (2019). Analgesic effects of eucalyptus essential oil in mice. Korean J. Pain 32 (2), 79-86. doi:10.3344/kjp. 2019.32.2.79

Li, F. S., and Weng, J. K. (2017). Demystifying traditional herbal medicine with modern approach. Nat. Plants 3 (8), 17109. doi:10.1038/nplants.2017.109

Li, W., Chen, Y., Wang, X., and Qu, S. (1991). [Pharmacological studies on the volatile oil isolated from the leaves of Pinus pumila (Pall.) Regel]. Zhongguo Zhong Yao Za Zhi 16 (3), 172-192.

Liberati, A., Altman, D. G., Tetzlaff, J., Mulrow, C., Gøtzsche, P. C., Ioannidis, J. P., et al. (2009). The PRISMA statement for reporting systematic reviews and meta-analyses of studies that evaluate health care interventions: explanation and elaboration. PLos Med. 6, e1000100. doi:10.1371/journal.pmed.1000100

Lima, G. M., Quintans-Júnior, L. J., Thomazzi, S. M., Almeida, E. M. S. A., Melo, M. S., Serafini, M. R., et al. (2012). Phytochemical screening, antinociceptive and anti-inflammatory activities of Chrysopogon zizanioides essential oil. Braz. J. Pharmacognosy 22 (2), 443-450. doi:10.1590/S0102-695X2012005000002

Linciano, P., Citti, C., Russo, F., Tolomeo, F., Laganà, A., Capriotti, A. L., et al. (2020). Identification of a new cannabidiol n-hexyl homolog in a medicinal cannabis variety with an antinociceptive activity in mice: cannabidihexol. Sci. Rep. 10 (1), 22019. doi:10.1038/s41598-020-79042-2

Lizarraga-Valderrama, L. R. (2020). Effects of essential oils on central nervous system: focus on mental health. Phytother Res. [Epub ahead of print]. doi:10. $1002 /$ ptr.6854

López, V., Nielsen, B., Solas, M., Ramírez, M. J., and Jäger, A. K. (2017). Exploring pharmacological mechanisms of lavender (lavandula angustifolia) essential oil on central nervous system targets. Front. Pharmacol. 8, 280. doi:10.3389/fphar. 2017.00280

Macleod, M. R., O'Collins, T., Howells, D. W., and Donnan, G. A. (2004). Pooling of animal experimental data reveals influence of study design and publication bias. Stroke 35 (5), 1203-1208. doi:10.1161/01.STR.0000125719.25853.20

Mikolajewicz, N., and Komarova, S. V. (2019). Meta-analytic methodology for basic research: a practical guide. Front. Physiol. 10, 203. doi:10.3389/fphys.2019.00203

Miraghazadeh, S. G., Shafaroodi, H., and Asgarpanah, J. (2015). Analgesic and antiinflammatory activities of the essential oil of the unique plant Zhumeria majdae. Nat. Prod. Commun. 10 (4), 669-672. doi:10.1590/s2175-97902019000217011

Mishra, D., Bisht, G., Mazumdar, P. M., and Sah, S. P. (2010). Chemical composition and analgesic activity of Senecio rufinervis essential oil. Pharm. Biol. 48 (11), 1297-1301. doi:10.3109/13880209.2010.491083

Moher, D., Liberati, A., Tetzlaff, J., Altman, D. G., and Group, P. (2009). Preferred reporting items for systematic reviews and meta-analyses: the PRISMA statement. PLos Med. 6, e1000097. doi:10.1371/journal.pmed.1000097

Morrone, L. A., Rombolà, L., Pelle, C., Corasaniti, M. T., Zappettini, S., Paudice, P., et al. (2007). The essential oil of bergamot enhances the levels of amino acid neurotransmitters in the hippocampus of rat: implication of monoterpene hydrocarbons. Pharmacol. Res. 55 (4), 255-262. doi:10.1016/ j.phrs.2006.11.010

Morrone, L. A., Scuteri, D., Rombolà, L., Mizoguchi, H., and Bagetta, G. (2017). Opioids resistance in chronic pain management. Curr. Neuropharmacol 15 (3), 444-456. doi:10.2174/1570159X14666161101092822

Neves, I. A., Rezende, S. R. F., Kirk, J. M., Pontes, E. G., de Carvalho, M., and Gamble, A. (2017). Composition and larvicidal activity of essential oil of Eugenia candolleana DC. (MYRTACEAE) against Aedes aegypti. Rev. Virtual Quim. 9 (6), 2305-2315. doi:10.21577/1984-6835.20170138

Nogueira, Lde. M., Da Silva, M. R., Dos Santos, S. M., De Albuquerque, J. F., Ferraz, I. C., de Albuquerque, T. T., et al. (2015). Antinociceptive effect of the essential oil obtained from the leaves of croton cordiifolius baill. (Euphorbiaceae) in mice. Evid. Based Complement. Alternat Med. 2015, 620865. doi:10.1155/2015/ 620865 
Park, Y., Jung, S. M., Yoo, S. A., Kim, W. U., Cho, C. S., Park, B. J., et al. (2015). Antinociceptive and anti-inflammatory effects of essential oil extracted from Chamaecyparis obtusa in mice. Int. Immunopharmacol 29 (2), 320-325. doi:10. 1016/j.intimp.2015.10.034

Perry, N. S., Houghton, P. J., Theobald, A., Jenner, P., and Perry, E. K. (2000). Invitro inhibition of human erythrocyte acetylcholinesterase by salvia lavandulaefolia essential oil and constituent terpenes. J. Pharm. Pharmacol. 52 (7), 895-902. doi:10.1211/0022357001774598

Queiroz, J. C., Antoniolli, A. R., Quintans-Júnior, L. J., Brito, R. G., Barreto, R. S., Costa, E. V., et al. (2014). Evaluation of the anti-inflammatory and antinociceptive effects of the essential oil from leaves of xylopia laevigata in experimental models. Sci. World J. 2014, 816450. doi:10.1155/2014/816450

Quintans, J. S., Alves, R. D., Santos, D. A., Serafini, M. R., Alves, P. B., Costa, E. V., et al. (2017). Antinociceptive effect of Aristolochia trilobata stem essential oil and 6-methyl-5-hepten-2yl acetate, its main compound, in rodents. $Z$. Naturforsch C J. Biosci. 72 (3-4), 93-97. doi:10.1515/znc-2016-0053

Quintans, J. S., Antoniolli, A. R., Almeida, J. R., Santana-Filho, V. J., and QuintansJúnior, L. J. (2014). Natural products evaluated in neuropathic pain models - a systematic review. Basic Clin. Pharmacol. Toxicol. 114 (6), 442-450. doi:10. $1111 /$ bcpt.12178

Ribeiro, S. (2018). "Whole organisms or pure compounds? Entourage effect versus drug specificity," in Plant medicines, healing and psychedelic science. Editors B. Labate and C. Cavnar (Cham: Springer).

Rice, A. S. C., Morland, R., Huang, W., Currie, G. L., Sena, E. S., and Macleod, M. R. (2013). Transparency in the reporting of in vivo pre-clinical pain research: the relevance and implications of the ARRIVE (Animal Research: reporting in Vivo Experiments) guidelines. Scand. J. Pain 4 (2), 58-62. doi:10.1016/j.sjpain.2013. 02.002

Rombolà, L., Tridico, L., Scuteri, D., Sakurada, T., Sakurada, S., Mizoguchi, H., et al. (2017). Bergamot essential oil attenuates anxiety-like behaviour in rats. Molecules 22 (4), 614. doi:10.3390/molecules22040614

Rombolà, L., Scuteri, D., Adornetto, A., Straface, M., Sakurada, T., Sakurada, S., et al. (2019). Anxiolytic-like effects of bergamot essential oil are insensitive to flumazenil in rats. Evid. Based Complement. Alternat Med. 2019, 2156873. doi:10.1155/2019/2156873

Rombolà, L., Scuteri, D., Watanabe, C., Sakurada, S., Hamamura, K., Sakurada, T., et al. (2020). Role of 5-HT1A receptor in the anxiolytic-relaxant effects of bergamot essential oil in rodent. Int. J. Mol. Sci. 21 (7), 2597. doi:10.3390/ ijms 21072597

Ryan, R. (2019). Cochrane Consumers and Communication Review Group: data synthesis and analysis. Available at: http://cccrg.cochrane.org (Accessed March 13, 2019).

Sakurada, T., Mizoguchi, H., Kuwahata, H., Katsuyama, S., Komatsu, T., Morrone, L. A., et al. (2011). Intraplantar injection of bergamot essential oil induces peripheral antinociception mediated by opioid mechanism. Pharmacol. Biochem. Behav. 97 (3), 436-443. doi:10.1016/j.pbb.2010.09.020

Sarmento-Neto, J. F., do Nascimento, L. G., Felipe, C. F., and de Sousa, D. P. (2015). Analgesic potential of essential oils. Molecules 21 (1), E20. doi:10.3390/ molecules 21010020

Savelev, S., Okello, E., Perry, N. S., Wilkins, R. M., and Perry, E. K. (2003). Synergistic and antagonistic interactions of anticholinesterase terpenoids in Salvia lavandulaefolia essential oil. Pharmacol. Biochem. Behav. 75 (3), 661-668. doi:10.1016/s0091-3057(03)00125-4

Savelev, S. U., Okello, E. J., and Perry, E. K. (2004). Butyryl- and acetylcholinesterase inhibitory activities in essential oils of Salvia species and their constituents. Phytother Res. 18 (4), 315-324. doi:10.1002/ptr.1451

Scherder, E. J., Sergeant, J. A., and Swaab, D. F. (2003). Pain processing in dementia and its relation to neuropathology. Lancet Neurol. 2 (11), 677-686. doi:10.1016/ s1474-4422(03)00556-8

Scuteri, D., Morrone, L. A., Rombolà, L., Avato, P. R., Bilia, A. R., Corasaniti, M. T., et al. (2017a). Aromatherapy and aromatic plants for the treatment of behavioural and psychological symptoms of dementia in patients with alzheimer's disease: clinical evidence and possible mechanisms. Evid. Based Complement. Alternat Med. 2017, 9416305. doi:10.1155/2017/9416305

Scuteri, D., Piro, B., Morrone, L. A., Corasaniti, M. T., Vulnera, M., and Bagetta, G. (2017b). The need for better access to pain treatment: learning from drug consumption trends in the USA. Funct. Neurol. 22 (4), 229-230. doi:10.11138/ fneur/2017.32.4.229
Scuteri, D., Crudo, M., Rombolà, L., Watanabe, C., Mizoguchi, H., Sakurada, S., et al. (2018a). Antinociceptive effect of inhalation of the essential oil of bergamot in mice. Fitoterapia 129, 20-24. doi:10.1016/j.fitote.2018. 06.007

Scuteri, D., Garreffa, M. R., Esposito, S., Bagetta, G., Naturale, M. D., and Corasaniti, M. T. (2018b). Evidence for accuracy of pain assessment and painkillers utilization in neuropsychiatric symptoms of dementia in Calabria region, Italy. Neural Regen. Res. 13 (9), 1619-1621. doi:10.4103/1673-5374. 237125

Scuteri, D., Rombolà, L., Morrone, L. A., Bagetta, G., Sakurada, S., Sakurada, T., et al. (2019a). Neuropharmacology of the neuropsychiatric symptoms of dementia and role of pain: essential oil of bergamot as a novel therapeutic approach. Int. J. Mol. Sci. 20 (13), 3327. doi:10.3390/ijms20133327

Scuteri, D., Rombolá, L., Tridico, L., Mizoguchi, H., Watanabe, C., Sakurada, T., et al. (2019b). Neuropharmacological properties of the essential oil of bergamot for the clinical management of pain-related BPSDs. Curr. Med. Chem. 26 (20), 3764-3774. doi:10.2174/0929867325666180307115546

Scuteri, D., Berliocchi, L., Rombolà, L., Morrone, L. A., Tonin, P., Bagetta, G., et al. (2020a). Effects of aging on formalin-induced pain behavior and analgesic activity of gabapentin in C57BL/6 mice. Front. Pharmacol. 11, 663. doi:10.3389/ fphar.2020.00663

Scuteri, D., Mantovani, E., Tamburin, S., Sandrini, G., Corasaniti, M. T., Bagetta, G., et al. (2020b). Opioids in post-stroke pain: a systematic review and meta-analysis. Front. Pharmacol. [Epub ahead of print]. doi:10.3389/fphar.2020.587050

Scuteri, D., Matamala-Gomez, M., Bottiroli, S., Corasaniti, M. T., De Icco, R., Bagetta, G., et al. (2020c). Pain assessment and treatment in dementia at the time of coronavirus disease COVID-19. Front. Neurol. 11, 890. doi:10.3389/ fneur.2020.00890

Scuteri, D., Rombolà, L., Morrone, L. A., Monteleone, D., Corasaniti, M. T., Sakurada, T., et al. (2020d). "Exploitation of aromatherapy in dementiaimpact on pain and neuropsychiatric symptoms," in The neuroscience of dementia: diagnosis and management in dementia. Editors V. R. Preedy and C. R. Martin (San Diego: Academic Press), 713-726.

Scuteri, D., Rombolà, L., Watanabe, C., Sakurada, S., Corasaniti, M. T., Bagetta, G., et al. (2020e). Impact of nutraceuticals on glaucoma: a systematic review. Prog. Brain Res. 257, 141-154. doi:10.1016/bs.pbr.2020.07.014

Scuteri, D., Vulnera, M., Piro, B., Bossio, R. B., Morrone, L. A., Sandrini, G., et al. (2020f). Pattern of treatment of behavioural and psychological symptoms of dementia and pain: evidence on pharmacoutilization from a large real-world sample and from a centre for cognitive disturbances and dementia. Eur. J. Clin. Pharmacol. [Epub ahead of print]. doi:10.1007/s00228-020-02995-w

Sharif, M., Najafizadeh, P., Asgarpanah, J., and Mousavi, Z. (2020). In vivo analgesic and anti-inflammatory effects of the essential oil from Tanacetum balsamita L. Braz. J. Pharm. Sci. 56, e18357. doi:10.1590/s217597902019000418357

Sofi, P. A., Zeerak, N. A., and Singh, P. (2009). Kala zeera (Bunium persicum Bioss.): a Kashmirian high value crop. Turkish J. Biol. 33, 249-258. doi:10.3906/ biy-0803-18

Stein, C., Hopfeld, J., Lau, H., and Klein, J. (2015). Effects of ginkgo biloba extract EGb 761, donepezil and their combination on central cholinergic function in aged rats. J. Pharm. Pharm. Sci. 18 (4), 634-646. doi:10.18433/j3wc8v

Sterne, J. A., and Egger, M. (2001). Funnel plots for detecting bias in meta-analysis: guidelines on choice of axis. J. Clin. Epidemiol. 54 (10), 1046-1055. doi:10.1016/ s0895-4356(01)00377-8

Sterne, J. A. C., Savović, J., Page, M. J., Elbers, R. G., Blencowe, N. S., Boutron, I., et al. (2019). RoB 2: a revised tool for assessing risk of bias in randomised trials. BMJ 366, 14898. doi:10.1136/bmj.14898

Sulaiman, M. R., Tengku Mohamad, T. A., Shaik Mossadeq, W. M., Moin, S., Yusof, M., Mokhtar, A. F., et al. (2010). Antinociceptive activity of the essential oil of Zingiber zerumbet. Planta Med. 76 (2), 107-112. doi:10.1055/s-00291185950

Suokas, A. K., Sagar, D. R., Mapp, P. I., Chapman, V., and Walsh, D. A. (2014). Design, study quality and evidence of analgesic efficacy in studies of drugs in models of OA pain: a systematic review and a meta-analysis. Osteoarthr Cartil 22 (9), 1207-1223. doi:10.1016/j.joca.2014.06.015

Todorova, M., Trendafilova, A., Ivanova, V., Danova, K., and Dimitrov, D. (2017). Essential oil composition of Inula britannica L. from Bulgaria. Nat. Prod. Res. 31 (14), 1693-1696. doi:10.1080/14786419.2017.1285295 
Turk, D. C., Dworkin, R. H., Allen, R. R., Bellamy, N., Brandenburg, N., Carr, D. B., et al. (2003). Core outcome domains for chronic pain clinical trials: IMMPACT recommendations. Pain 106 (3), 337-345. doi:10.1016/j.pain.2003.08.001

Ulku Karabay-Yavasoglu, N., Baykan, S., Ozturk, B., Apaydin, S., and Tuglular, I. (2006). Evaluation of the antinociceptive and anti-inflammatory activities of Satureja thymbra. L. Essential oil. Pharm. Biol. 44 (8), 585-591. doi:10.1080/ 13880200600896827

Venâncio, A. M., Marchioro, M., Estavam, C. S., Melo, M. S., Santana, M. T., Onofre, A. S. C., et al. (2011). Ocimum basilicum leaf essential oil and (-)-linalool reduce orofacial nociception in rodents: a behavioral and electrophysiological approach. Braz. J. Pharmacognosy 21 (6), 1043-1051. doi:10.1590/S0102-695X2011005000147

Wood, H. C., and Reichut, E. T. (1880). Note on the action upon the circulation of certain volatile oils. J. Physiol. 2, 446. doi:10.1113/jphysiol.1880.sp000073

Ximenes, R. M., De Morais Nogueira, L., Cassundé, N. M., Jorge, R. J., Dos Santos, S. M., Magalhães, L. P., et al. (2013). Antinociceptive and wound healing activities of Croton adamantinus Müll. Arg. essential oil. J. Nat. Med. 67 (4), 758-764. doi:10.1007/s11418-012-0740-1

Zarei, M., Mohammadi, S., and Komaki, A. (2018). Antinociceptive activity of Inula britannica L. and patuletin: in vivo and possible mechanisms studies. J. Ethnopharmacol 219, 351-358. doi:10.1016/j.jep.2018.03.021

Zaynoun, S. T., Johnson, B. E., and Frain-Bell, W. (1977). A study of oil of bergamot and its importance as a phototoxic agent. I. Characterization and quantification of the photoactive component. Br. J. Dermatol. 96 (5), 475-482. doi:10.1111/j. 1365-2133.1977.tb07149.x

Zendehdel, M., Torabi, Z., and Hassanpour, S. (2015). Antinociceptive mechanisms of Bunium persicum essential oil in the mouse writhing test: role of opioidergic and histaminergic systems. Veterinarni Medicina 60 (2), 63-70. doi:10.17221/7988-VETMED

Zhang, L., Li, D., Cao, F., Xiao, W., Zhao, L., Ding, G., et al. (2018). Identification of human acetylcholinesterase inhibitors from the constituents of EGb761 by modeling docking and molecular dynamics simulations. Comb. Chem. High Throughput Screen. 21 (1), 41-49. doi:10. 2174/1386207320666171123201910

Conflict of Interest: The authors declare that the research was conducted in the absence of any commercial or financial relationships that could be construed as a potential conflict of interest.

Copyright (c) 2021 Scuteri, Hamamura, Sakurada, Watanabe, Sakurada, Morrone, Rombolà, Tonin, Bagetta and Corasaniti. This is an open-access article distributed under the terms of the Creative Commons Attribution License (CC BY). The use, distribution or reproduction in other forums is permitted, provided the original author(s) and the copyright owner(s) are credited and that the original publication in this journal is cited, in accordance with accepted academic practice. No use, distribution or reproduction is permitted which does not comply with these terms. 